\title{
THE APPLICATION OF PROBABILITY ELEMENTS IN OPTIMIZING SUPPLY OF SPARE PARTS AND COMPONENTS IN AVIATION
}

\author{
ZASTOSOWANIE ELEMENTÓW PROBABILISTYKI \\ W OPTYMALIZACJI WIELKOŚCI ZAPASÓW CZEŚCI \\ ZAMIENNYCH I PODZESPOLÓW W LOTNICTWIE
}

\author{
Norbert Grzesik, Tomasz Iwan
}

Polish Air Force Academy. Wyższa Szkoła Oficerska Sił Powietrznych

\begin{abstract}
The paper undertakes the problem of managing exploitation support of aviation equipment in terms of spare parts and subassemblies taking into account variable conditions, resulting from different intensity of aircraft and helicopter operation. It covers the practical aspects of planning stocks of material resources in connection with the applicable operating systems and failure of aircraft at the airbase level. By using statistical elements and probabilistic models it indicates the possibility of increasing the availability of parts and aircraft components, which in the long run will make a positive impact on the level of equipment technical efficiency. The article points to the need to minimize the expenditure involved and to avoid redundant, useless aircraft spare parts and components. Therefore, it is aimed at increasing the efficiency of material management, improving safety and developing exploitation systems in terms of technical reliability.
\end{abstract}

Keywords: Equipment exploitation, spare parts, optimization, probabilistic methods, stocks

Streszczenie: Referat podejmuje problematyke zarządzania procesem wsparcia eksploatacji sprzętu lotniczego $w$ zakresie części zamiennych $i$ podzespolów uwzględniajac zmienne warunki wynikajace z różnej intensywności eksploatacji samolotów i śmigłowców. Obejmuje on swym zakresem praktyczne aspekty planowania zapasów technicznych środków materiatowych $w$ powiazaniu z obowiazującymi systemami eksploatacji $i$ awaryjnościa statków powietrznych na poziomie bazy lotniczej. Przy wykorzystaniu elementów statystyki oraz modeli probabilistycznych wskazuje na możliwości zwiększenia dostępności części i podzespołów lotniczych, co $w$ dluższej perspektywie pozwoli korzystnie wptynać na poziom sprawności technicznej sprzetu. Opracowanie wskazuje na potrzebe minimalizacji ponoszonych nakładów i uniknięcia nadmiernych nie wykorzystywanych części i podzespołów lotniczych. Jest zatem ukierunkowane na zwiększenie efektywności gospodarki materiatowej, poprawe bezpieczeństwa oraz usprawnienie funkcjonowania systemu eksploatacji w aspekcie niezawodności technicznej.

Stowa kluczowe: eksploatacja sprzętu, części zamienne, optymalizacja, metody probabilistyczne, zapasy 
The application of probability elements in optimizing supply of spare parts... Zastosowanie elementów probabilistyki w optymalizacji wielkości zapasów...

\section{THE APPLICATION OF PROBABILITY ELEMENTS IN OPTIMIZING SUPPLY OF SPARE PARTS AND COMPONENTS IN AVIATION}

\section{Introduction}

The complexity of exploitation systems in various branches of industry, companies and institutions is related to a high flow rate of materials, subassemblies and finished products. Streams of services, information and financial resources in an environment of technical infrastructure are always closely synchronized with them. Aviation technology equipment constitutes highly specific and important group of technical devices. The adopted assumptions resulting from the binding scheduled preventive maintenance system are designed to ensure the maximum level of safety in the execution of air operations and simultaneously high availability (airworthiness) of aircraft. ${ }^{1}$ Consequently, it seems justified to undertake all possible measures to minimize the risk of low or none spare parts (subassemblies) inventories for airplanes and helicopters, thereby avoiding massive delays. A specific feature of components and any technical material means for this type of equipment is obviously their purchase value and "freezing" of major capital in the absence of lack of demand for the above-mentioned assortment. Failure and thus the 'demand' for spare parts can often be difficult to define, since the incidence of damage is a random variable. It should also be mentioned that a degree in the intensity of wear of the particular parts and components is usually non-uniform and therefore unpredictable. In addition, long-term storage of aircraft parts unfortunately results in a gradual decrease in their technical and operational properties, among others, natural aging of construction materials and decalibration of performance parameter settings. Thus forecasting for most groups of spare parts is complicated and requires an in-depth analysis of numerous factors such as the intensity of operation of aircraft equipment, the age structure and the size and nature of the demand in previous time intervals.

Below there is a graph of inventory expenditures and revenues of a particular group of spare parts within the annual settlement period - Fig 1.

In the time interval A there is a certain material turnover which is not particularly systematic followed by a period in which there are no inventory changes. Area B starts with fast consumption of the whole stock of spare parts, followed by some cycles of recovery and consumption of the stock. In area $\mathrm{C}$ there is a dramatic spike in the level of the inventories presumably caused by the return of previously collected and unused parts. Such a situation can occur in a number of entities, since the parts which are taken from the depot are often not controlled and their actual status in the exploitation system remains unknown.

\footnotetext{
${ }^{1}$ Zob. Instrukcja stużby inżynieryjno - lotniczej lotnictwa Sit Zbrojnych RP, Bydgoszcz 2017
} 
The surpluses are usually revealed as a result of subsequent stock-taking and on retaking into storage of the goods ${ }^{2}$.

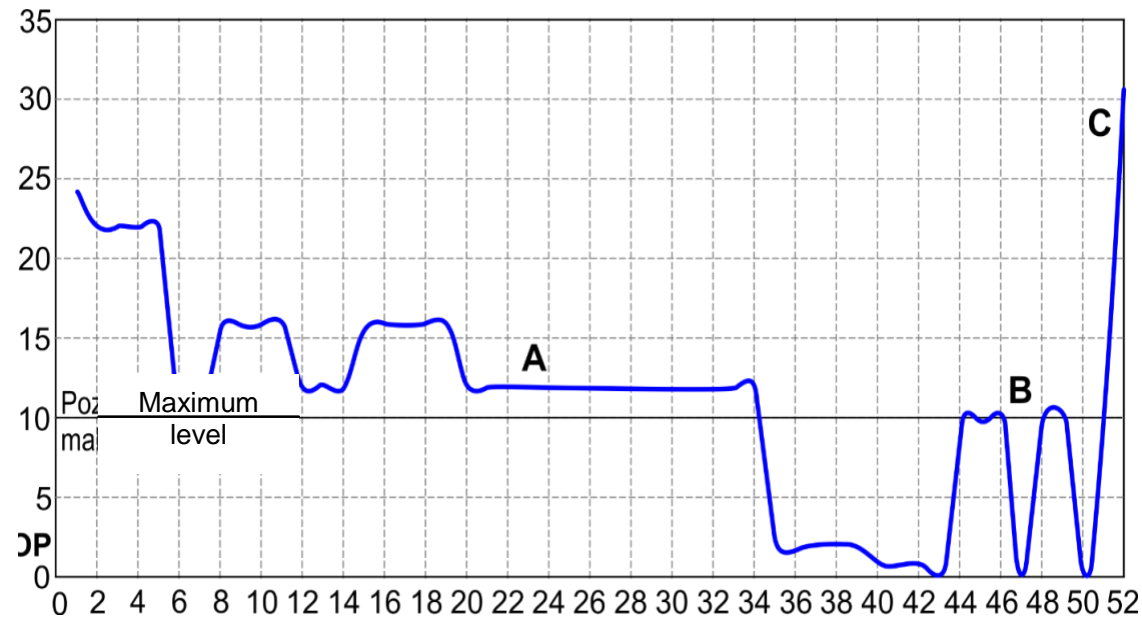

Fig. 1 The course of the actual inventory for the selected item of supply Source [21]

\section{The structure of stock spare parts}

The inventories of spare parts as referred to the system of exploitation of technical equipment can have a big turnover in the assumed settlement period, although there may also be some product groups, for which demand is negligible or even nonexistent. A simplified model structure of the stock, which can also be applied in the case of spare parts is provided in Fig. 2.

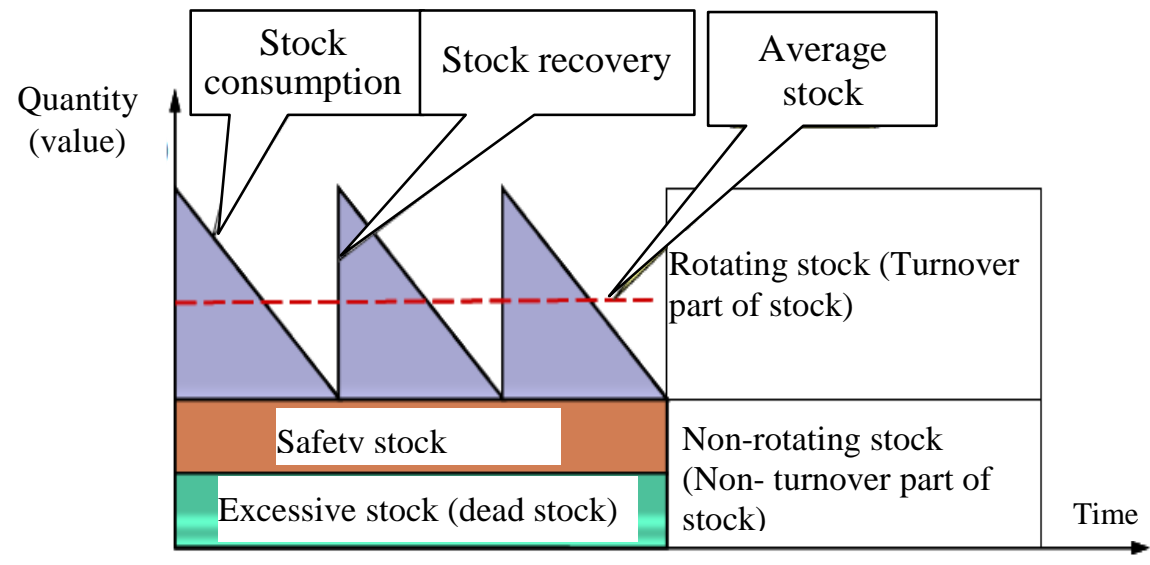

Fig. 2 Model structure of stocks of spare parts. Source [24]

\footnotetext{
${ }^{2}$ Mączyński, 2013: 51-53
} 
The application of probability elements in optimizing supply of spare parts... Zastosowanie elementów probabilistyki w optymalizacji wielkości zapasów...

\section{Classifications of spare parts in forecasting demand}

Independent demand for spare parts is random by nature, being usually subject to forecasting based on data from previous periods. Therefore, when planning the supply, one of the most effective methods to control the future steering of the level and the goods structure is the $\mathbf{A B C}$ classification of technical material resources in three groups:

- group A - inventories of "vital few" parts, constituting merely 5 to $20 \%$ of the number of assortment stock, but with a significant share in value, reaching $75 \div 80 \%$; this group of high-value and (or) a high proportion of the total cost of materials should be treated with special attention to the proper management of inventory levels. The group may include special parts which are often irreplaceable and with the longest time of delivery,

- group B - parts and materials having a share of 15 to $20 \%$ both in the number of inventory goods and their value (the middle group). The group often consists of standard parts, produced by a number of manufacturers and applicable to different types of equipment,

- group C - mass materials (trivial many), with the largest share in the number of inventory $(60 \div 80 \%)$ and a very low proportion of their value (approximately $5 \%$ ). The group may typically include easily available exploitation materials for single use, common to many machines and equipment. ${ }^{3}$

The proportions of the individual groups of stocks are arranged approximately in the following way: $20 \%$ of the items constitute up to $80 \%$ in terms of their value, therefore the ABC method is also referred to as the "80/20" principle or the Vilfred Pareto principle. ${ }^{4}$

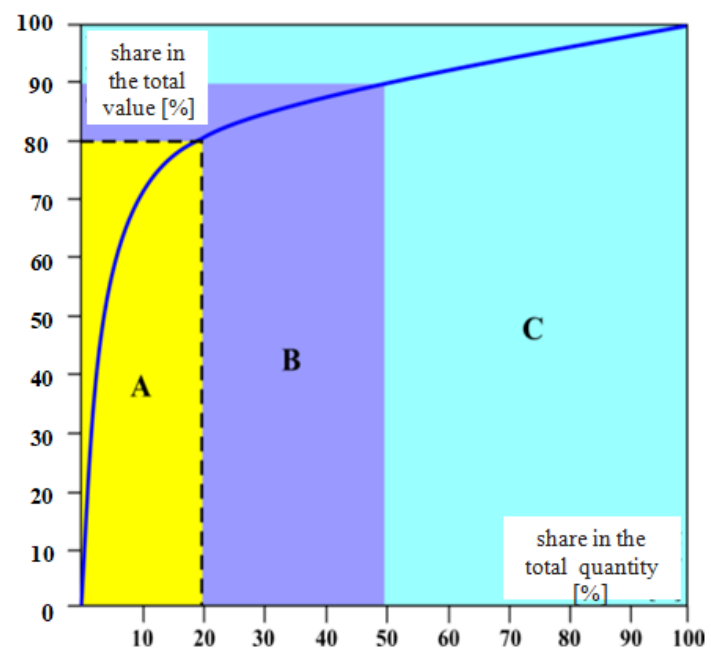

Fig. 3 Graphic illustration of the "Pareto principle". Source [16]

\footnotetext{
${ }^{3}$ Krzyżaniak, 2005: 20-25

${ }^{4}$ Kisperska-Moroń, Krzyżaniak (red) 2009: 67-68
} 
With regard to group A, reasonable presumptions indicate a justified use of a strict regime when placing orders for parts, while with respect to other materials, especially in group C ( "the cheapest") it is possible to place the orders and make inventories in a more free manner.

The statistical data from earlier periods are also used to determine the regularity and the variability of data in the range of goods. Therefore, effective complementing of the $80 / 20$ " principle is an XYZ method relating to the regularity of the demand for stock in an assumed settlement period; the particular types of materials are divided into three groups:

- group X - the parts and components for which there is a regular demand (wellrotating) with a relatively high accuracy of forecasting the supplies;

- group Y - parts and components for which demand is seasonal or compatible with a specific trend (medium rotational), with an average accuracy of forecasting the supplies;

- Group Z - materials with very irregular demand (poorly rotational) and low accuracy of forecasting the demand.

In the theory of inventory control of spare parts for aviation technology, at the level of military units, it may become reasonable to make a synthesis of both methods, though it is possible to obtain nine combinations to separate key material groups. ${ }^{5}$

The combination of $\mathrm{ABC}$ and $\mathrm{XYZ}$ analyses allows a differentiated approach to inventory management of individual items, from the most significant in value and regularly rotating (easily forecast) - AX group to those which are insignificant in value and sold sporadically - group CZ. Therefore, in the management of the size of stocks it is reasonable to focus particularly on the exact planning of orders in the groups of goods with the highest value and precision in the forecasting of the supplies (groups AX, BX and AY).

Tab. 1 Listing of $A B C$ and $X Y Z$ classifications for spare parts

\begin{tabular}{|c|c|c|c|c|}
\hline & \multicolumn{3}{|c|}{ Stock value } \\
\hline & & $\mathbf{A}$ & B & $\mathrm{C}$ \\
\hline \multirow{3}{*}{ 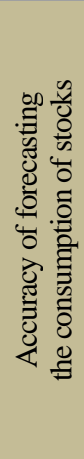 } & $\mathbf{X}$ & $\begin{array}{l}\text { high value level of con- } \\
\text { sumption, high accuracy } \\
\text { of demand forecasting } \\
\text { (fluctuations below 20\%) }\end{array}$ & $\begin{array}{l}\text { average level of con- } \\
\text { sumption, high accuracy } \\
\text { of demand forecasting } \\
\text { (fluctuations below 20\%) }\end{array}$ & $\begin{array}{l}\text { low value level ofcon- } \\
\text { sumption, high accuracy } \\
\text { of demand forecasting } \\
\text { (fluctuations below 20\%) }\end{array}$ \\
\hline & $\mathbf{Y}$ & $\begin{array}{l}\text { high value level of con- } \\
\text { sumption, average accuracy } \\
\text { of demand forecasting } \\
\text { (fluctuations 20-50\%) }\end{array}$ & $\begin{array}{l}\text { average value ofconsum- } \\
\text { ption, average accuracy } \\
\text { of demand forecasting } \\
\text { (fluctuations } 20-50 \% \text { ) }\end{array}$ & $\begin{array}{l}\text { low level of consum- } \\
\text { ption, average accuracy } \\
\text { of demand forecasting } \\
\text { (fluctuations } 20-50 \% \text { ) }\end{array}$ \\
\hline & $\mathbf{Z}$ & $\begin{array}{l}\text { high level of consum- } \\
\text { ption, low accuracy } \\
\text { of demand forecasting } \\
\text { (fluctuations above } 50 \% \text { )) }\end{array}$ & $\begin{array}{l}\text { average value of consum- } \\
\text { ption, low accuracy of } \\
\text { forecasting (fluctuations } \\
\text { above } 50 \% \text { ) }\end{array}$ & $\begin{array}{l}\text { low level of consum- } \\
\text { ption, low accuracy } \\
\text { of demand forecasting } \\
\text { (fluctuations above } 50 \% \text { ) }\end{array}$ \\
\hline
\end{tabular}

Source: own research

\footnotetext{
${ }^{5}$ Krawczyk, t. 2, 2011: 194-198
} 
The application of probability elements in optimizing supply of spare parts... Zastosowanie elementów probabilistyki w optymalizacji wielkości zapasów...

In order to graphically illustrate the complex and multi-aspect issues of planning material supplies for aviation technology, below there is data, provided in a graphic form, with regard to the quantity (Fig. 4) and the value (Fig. 5) of stored spare parts for aircraft and helicopters in the previous years, on the example of a selected military unit ${ }^{6}$.

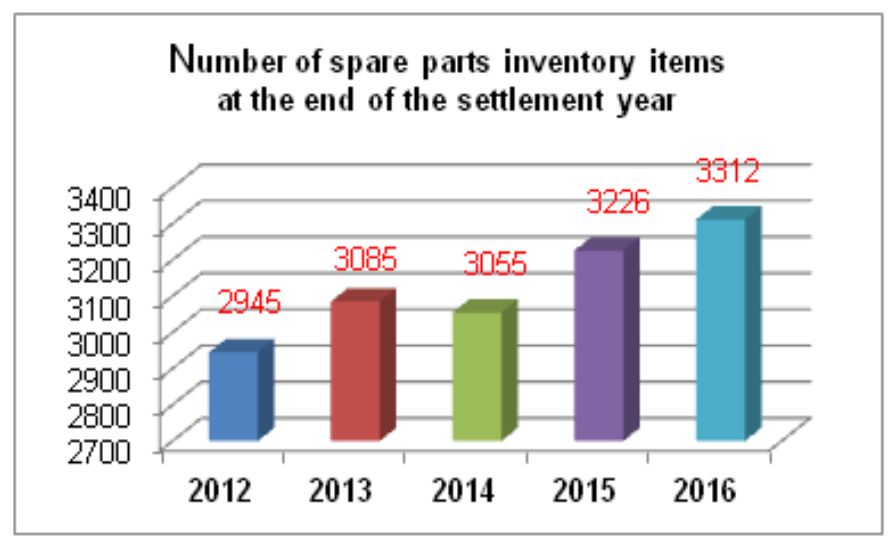

Fig. 4 Quantity listing of spare parts in the years $2012 \div 2016$ Source: own research

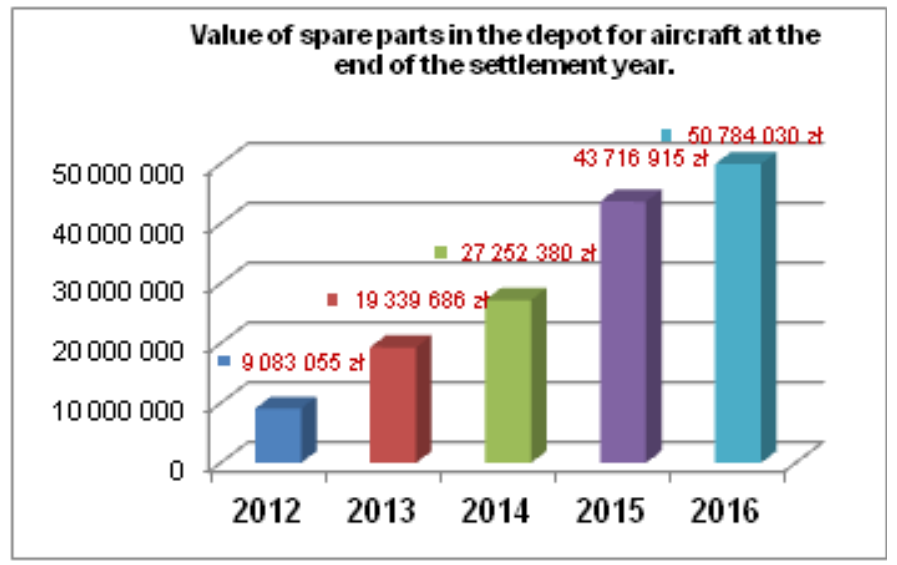

Fig. 5 Listing of spare parts for aircraft in the depot Source: own research

\footnotetext{
${ }^{6}$ All the details can be obtained from the author.
} 
Difficulties in planning demand for spare parts for aviation technology are confirmed by graphic relationships between the total quantity of stock items (types of spare parts and subassemblies) and their incoming and outgoing in the years 2014 and 2015 (Fig. 6). Figure 7 shows an analogous value listing of goods in stock - incoming and outgoing values.

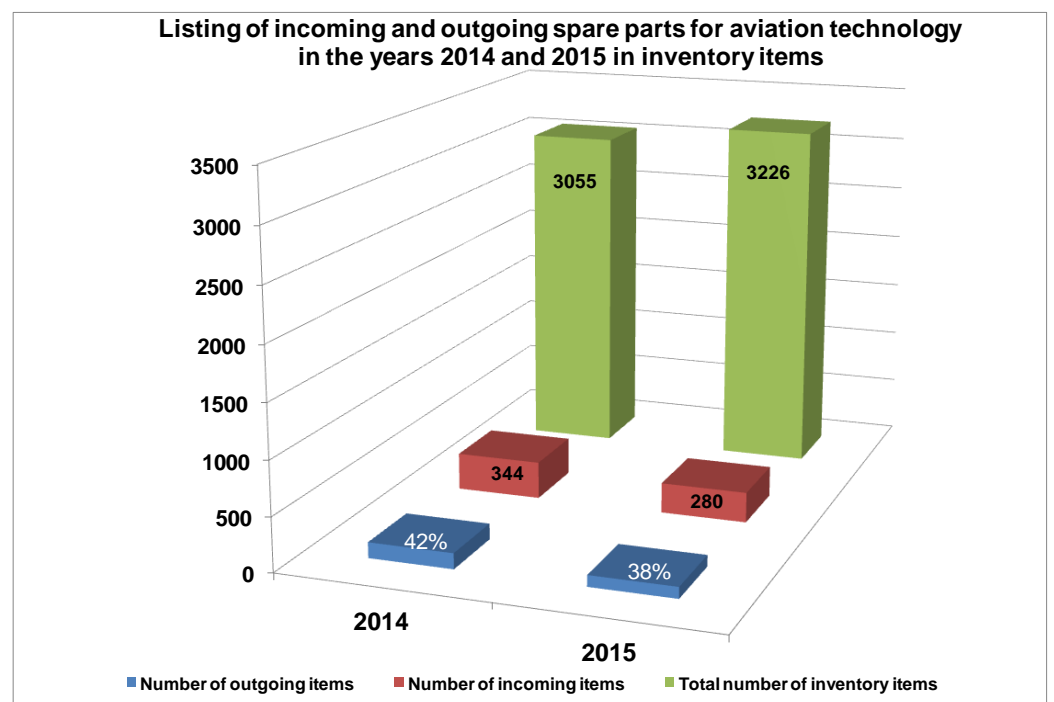

Fig. 6 Comparative summary of spare parts turnover in the years 2014 and 2015 Source: Own research, based on MAG-MAT and ZWSI RON accounting programmes

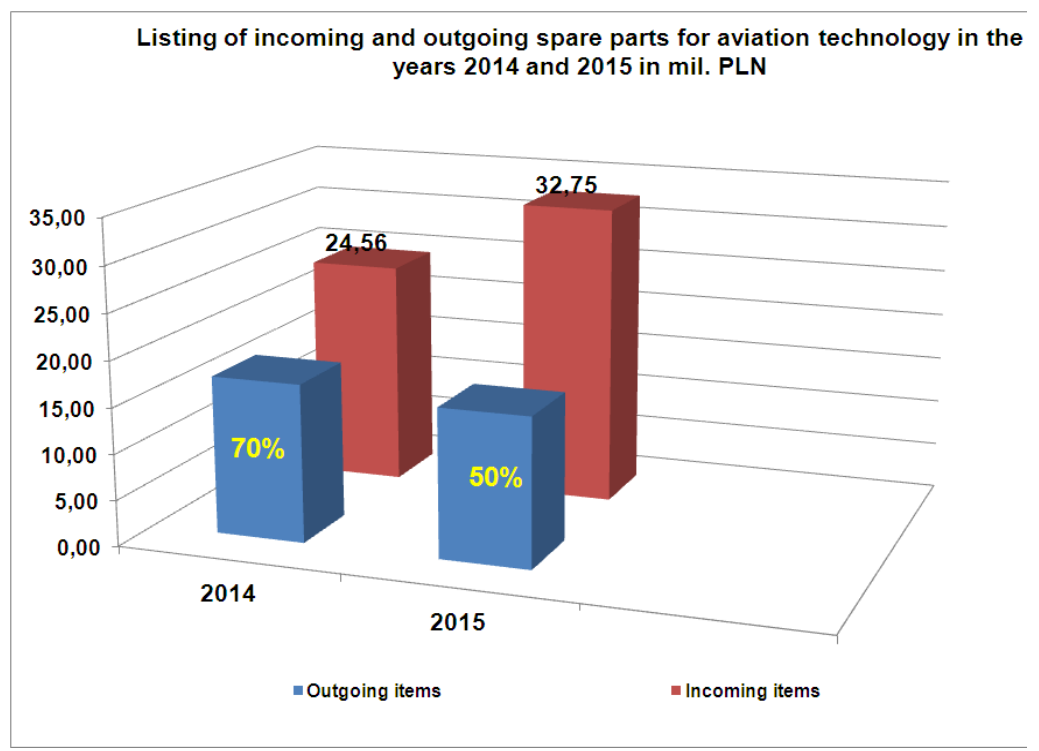

Fig. 7 Listing of values of spare parts turnover in the years 2014 and 2015 Source: own research based on MAG-MAT and ZWSI RON accounting programmes 
The application of probability elements in optimizing supply of spare parts... Zastosowanie elementów probabilistyki w optymalizacji wielkości zapasów...

On the example of the presented data of incoming and outgoing spare parts in the depot in the previous years, as well as after making a quantity and value analysis of the stored and issued goods, it must be stated that the value of the inventory assets is gradually increasing. This results from a smaller stream of outgoing aircraft parts from the depot compared to the incoming volume of goods. Overestimation of the size of orders in relation to the level of real needs, both in terms of quantity and value, is not a rare phenomenon, and also occurs in other branches of industry, such as the automotive or construction one. However, given the differences in size, it seems reasonable to reduce the disproportions between supply and demand in the supply of aircraft parts, or in other words optimize the general depot management.

\section{Elements of the probability calculus in inventory control}

The risk in operational management is an issue which is closely connected with the theory of inventory management, as it is not possible to forecast all the circumstances affecting independent demand for parts and separate subassemblies. In the case of machinery and equipment, demand for spare parts and exploitation materials depends on the technical reliability, which is the quantity characterising equipment capability to meet particular requirements. In other words, it will be the likelihood that a given object will be usable (efficient) within a certain period of time $\boldsymbol{T}$ or that the values of the parameters defining its relevant properties will not exceed the permissible limits in the adopted operating conditions. ${ }^{7}$ Therefore, the uncertainty and changeability of demand for materials will affect decisions as regards planning stocks and their later use in exploitation activities. In the figures below there is a comparison of data on the intensity of the operation of aircraft in previous years in a selected air force base expressed in general flying hours. ${ }^{8}$ In addition, for the years 2014-2016 total values of issued spare parts from a depot and used in aircraft are listed. From the above statements, it appears that the direct correlation between the intensity of exploitation of aviation equipment and value of new parts as well as subassemblies used in the process of the operation can be extremely complex in its character. It should also be noted that in the years 20142016 there were situations when with relatively smaller number of flying hours, the expenditure on spare parts was the highest.

This should be interpreted in the following way: higher failure rate of equipment hindered obtaining high operating efficiency and generated greater needs for spare parts and aircraft subassemblies. On the other hand, on the example of the year 2015, a relatively large number of the listed parts and subassemblies made it possible to obtain the highest indicator of flying hours. Obviously, the failure rate of equipment generating a demand for spare parts is a random variable, which is subject to specific rules.

\footnotetext{
${ }^{7}$ Macha: 2001: 7

${ }^{8}$ Data available from the author
} 


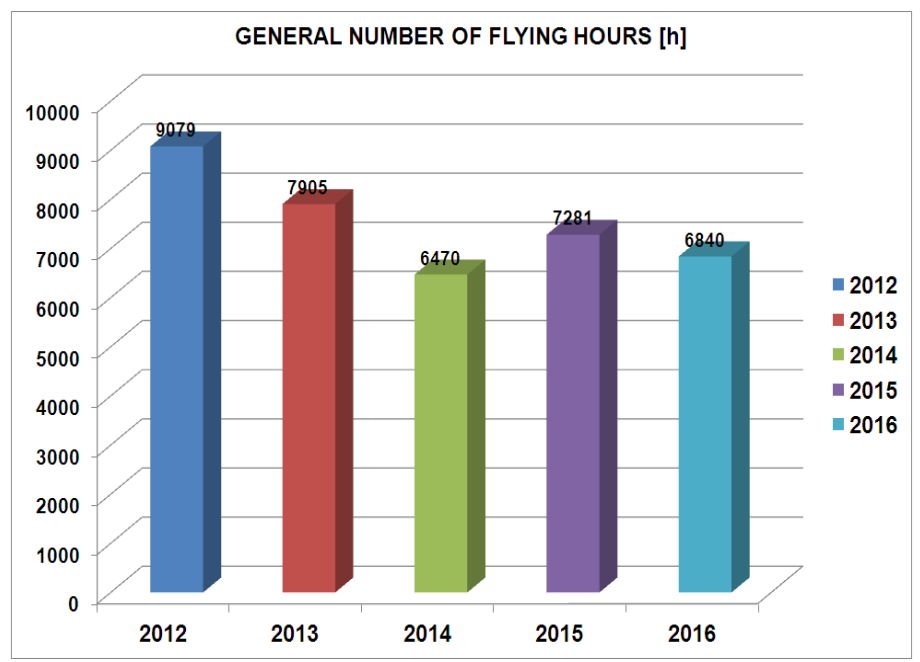

Fig. 8 Listing of flying hours in particular years

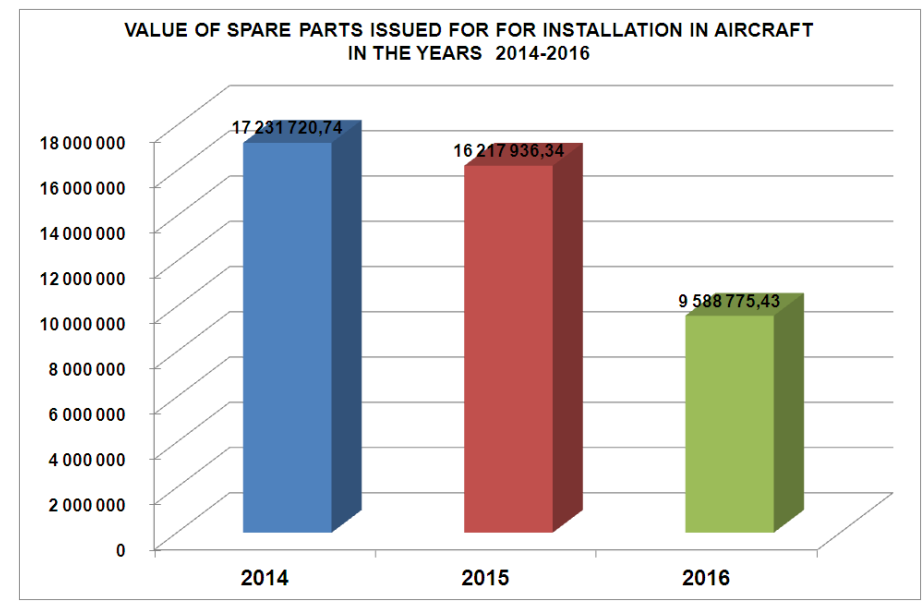

Fig. 9 Listing of the value of spare parts used in the Eprocess of operation of air technology in particular years

In specialist literature and the theory of inventory control of matching the theoretical distribution is made by comparing the average demand of its standard demand with its standard deviation or variance ${ }^{9}$.

The variance of forecasting the demand $\sigma \mathrm{d}$ is defined as an arithmetic mean of squared deviations of individual values of demand $\boldsymbol{P}_{i}$ from the arithmetic mean $\boldsymbol{P}_{\boldsymbol{m}}$ in the considered period.

9 Por. Mesjasz-Lech, 2011:1161 
The application of probability elements in optimizing supply of spare parts... Zastosowanie elementów probabilistyki w optymalizacji wielkości zapasów...

$$
\sigma_{P}^{2}=\frac{1}{n} \sum_{i-1}^{n}\left(P_{i}-P_{\mathrm{m}}\right)^{2}
$$

The standard deviation of demand is defined as the square root of the variance of demand.

$$
\sigma_{P}=\sqrt{\sigma_{P}^{2}}=\sqrt{\frac{1}{n} \sum_{i=1}^{n}\left(P_{i}-P_{\mathrm{m}}\right)^{2}}
$$

A very useful statistical indicator that shows the volatility of demand for parts in stock is the coefficient of relative variation, which is expressed in percentage of the reference of the standard deviation $\sigma$ d demand to its mean value $\boldsymbol{P}_{\boldsymbol{m}}$

$$
\Delta_{p}=\frac{\sigma_{p}}{P_{\mathrm{m}}} * 100 \%
$$

It illustrates a simple way what fluctuations demand was exposed to in relation to its average value in the previous period. Therefore, in order to simplify the interpretation of these concepts, the average demand for spare parts could be defined with a designation $\mathrm{P}_{\mathrm{m}} \pm \sigma_{\mathrm{p}}$ [an expression in the units of measurement] or $\mathrm{Pm} \pm \Delta_{\mathrm{p}}$ [expressed in \%]. The value of the above coefficient also indicates the speed of rotation and facilitates the classification of the goods to one of the groups of materials $\mathrm{X}, \mathrm{Y}$ or $\mathrm{Z}$.

In the planning of stocks of technical resources, commonly there are three basic probability distributions of the demand for technical material resources ${ }^{10}$.

Regular distribution - frequently used in the description of demand for inventory items in quick rotation, consumed in mass quantities and classified in Group X, and occasionally in group Y - for larger values of the coefficient of variation for demand ${ }^{11}$. Therefore, in the theory of inventory control, it is assumed that the demand for a specific assortment item selection is not subject to regular distribution, if the mean value of demand is much greater than the square of standard deviation (variance).

Poisson distribution (interval) describes the probability of events occurring on a relatively rare basis, which are independent of one other in the presence of a large number of experiences. Thus, it will reflect the demand for inventory items which are slowly rotating, expressed in nonnegative integers of pieces or sets. The application of Poisson distribution is possible when the mean value of demand $\boldsymbol{P}_{\boldsymbol{m}}$ is approximately equal to its variance, that is the relationship is true;

${ }^{10}$ Zob. Cieciura, Zacharski, 2007:184-186

${ }^{11}$ Krzyżaniak, 2009: Logistyka 1/2009 
The exponential distribution it is the third type of stochastic dependences also used in managing the level of logistics It is usually applied in the planning of inventory materials which are slow-rotating (for small values of consumption).With its help, it is also possible to describe the time of work of technical equipment between two successive failures, which in turn is reflected in the demand for variable parts. The demand for stockpile can be described with exponential distribution provided the standard deviation revolves around the average value.

The synthetic listing of probability distributions used in the theory of inventory as well as the conditions of use have been summarised in Table 2

Tab. 2 Criteria for the selection and application of probability distributions

\begin{tabular}{|c|c|c|c|c|}
\hline $\begin{array}{l}\text { Distribution } \\
\text { type }\end{array}$ & $\begin{array}{l}\text { Application of } \\
\text { distribution }\end{array}$ & $\begin{array}{c}\text { Dependencies } \\
\text { between } \\
\text { parameters of } \\
\text { distribution }\end{array}$ & $\begin{array}{l}\text { Value of } \\
\text { the } \\
\text { coefficient } \\
\text { of demand } \\
\text { variation }\end{array}$ & $\begin{array}{l}\text { Material } \\
\text { group in } \\
\text { accordance } \\
\text { with the } \\
\text { XYZ } \\
\text { classification }\end{array}$ \\
\hline Normal & $\begin{array}{l}\text { Goods consumed } \\
\text { in large quantities, } \\
\text { quickly rotating }\end{array}$ & $P_{\mathrm{sr}}>\sigma_{\mathrm{p}}^{2}$ & $\Delta_{\mathrm{p}}<<100 \%$ & $\mathrm{X}$ or $\mathrm{Y}$ \\
\hline Poisson & $\begin{array}{l}\text { Goods rarely } \\
\text { sought }\end{array}$ & $P_{\mathrm{s} r} \approx \sigma_{\mathrm{p}}^{2}$ & $\Delta_{\mathrm{p}}<100 \%$ & $\mathbf{Y}$ or $\mathrm{Z}$ \\
\hline Exponential & $\begin{array}{l}\text { Slowly rotating } \\
\text { materials (low } \\
\text { wear materials) }\end{array}$ & $P_{\text {śr }} \approx \sigma_{P}$ & $\Delta_{\mathrm{p}} \rightarrow 100 \%$ & $\mathbf{Z}$ or $\mathrm{Y}$ \\
\hline
\end{tabular}

$P m-$ mean value of demand, $\sigma_{p^{-}}$standard deviation of demand (standard forecast error) Source: own research based on [23].

The knowledge of basic parameters of the probability distribution in the form of the average demand forecast and the standard deviation facilitates planning of the size of spare parts inventory. Larger forecast needs and standard forecast error (standard deviation) entail greater safety stock margin. The size of the margin will also depend upon the adopted level of service needs. In specialist literature, there is also a concept of coefficient of confidence, which is defined as the probability that the demand for materials will not prove greater than the assumed one (from the average forecast demand). The likelihood of an event contrary to the occurrence of demand more than the average is defined as the risk coefficient ${ }^{12}$.

Dependence on the size of safety stock $\mathrm{Q}_{z}$ (SS) from the assumed level of maintenance is done using the so-called safety co-efficient $\omega$, whose value is subordinate to a specific type of probability distribution.

${ }^{12}$ Zob. Sarjusz-Wolski: 2000: 38 
The application of probability elements in optimizing supply of spare parts... Zastosowanie elementów probabilistyki w optymalizacji wielkości zapasów...

$$
S S=\omega * \sigma_{P T}
$$

gdzie: $\sigma_{P T}$ - standard deviation of demand (demand for stockpile) in a cycle of completing the stock (in general, standard forecast error).

A key issue is the selection of an appropriate mathematical model which reflects a random space in a way that is closest to the logistics reality. In order to properly shape the safety stock margin (securing), it is necessary to know the distribution of the demand in the general inventory of supplying stocks. The elements of mathematical statistics enable efficient identification of trends and elements of seasonal demand for materials and the uncertainty in planning material requirements can be essentially reduced to random deviations (impossible to eliminate, or sometimes even to predict).

It must be therefore concluded that the greater accuracy of forecasting future demand, the smaller securing stock margin for spare parts, which is necessary to ensure the desired level of customer service, and consequently lower costs of storing the supplies. ${ }^{13}$

\section{The essence and assumptions of optimization methods in the planning and organization of exploitation}

As pointed out earlier, in determining the level of service needs and related margin of safety stock margin of spare parts, the probability calculus ${ }^{14}$ is often used. A model pattern for the establishment of the level of stocks is presented in Fig. 10.

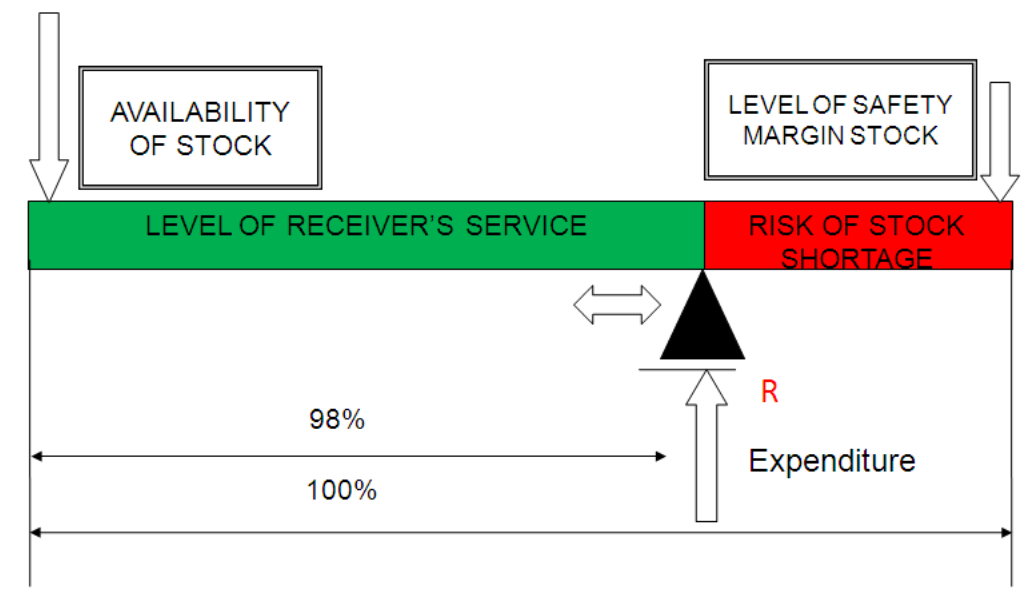

Fig. 10 Model diagram of the process of inventory management Source: own research based on [16] [18]

\footnotetext{
${ }^{13}$ Krzyżaniak, 2005: 43

${ }^{14}$ Kisperska-Moroń, Krzyżaniak (ed.), 2009; 113
} 
Assuming the level of customer service at a level of e.g. 98\% (probability of meeting the needs of spare parts in a given cycle of resupplying the stocks will equal 0.98), which means that the risk of a shortage of the stockpile will only be $2 \%$. Obviously it is possible to increase the likelihood of the lack of inventory (a symbolic shift of supporting a beam to the right), but at the same time, to keep the beam well-balanced, it is necessary to raise the level of safety stock margin, which in turn will result in an increase in the vertical reaction $\boldsymbol{R}$ of the supporting beam, and therefore an increase in total costs of stocks.

Exemplary indicators for the optimization of spare parts can therefore be:

- the total value of inventory,

- Number of technical equipment stops due to lack of parts,

- number of inventory items: high-speed and low-speed (in accordance with the ABC method),

- the intensity of inventory movements (in accordance with the XYZ analysis),

- reduction of inventory.

In view of the above, in order to achieve the set strategic objectives, it would be justified to adopt a general algorithm of the optimization procedure, which should include the following phases:

- analysis of failure of air equipment (indicator of technical efficiency);

- specifying the demand for spare parts for each type of equipment;

- assessment of the level of stocks of spare parts for aircraft and helicopters;

- estimation of risk and comparison of costs of shortage with the costs of keeping stocks;

- elimination of unused spare parts in recent years (obsolete materials);

- $\mathrm{ABC}$ value analysis of spare parts;

- specifying quantities for spare parts with low, normal and mass rotation.

Taking into account the fact that the acquisition value of most components can be significant or the delivery period (item recovery) may take up to several months, it would be necessary to estimate the risk of particular damage and costs of stoppage. It should also be added that the greatest difficulties in managing the size of the inventory occur in the case of spare parts, special and slow-rotating. It mav be particularly difficult to establish their initial stock with regard to equipment which is being introduced into service and in the absence of data on demand on supplies margin in previous timeframes. In such cases, it is essential to cover the following initial data:

- priority of technical equipment (devices) in an institution or an organizational unit;

- number of devices of a particular type in a company;

- number of items of a given part (subassemblies) mounted in the equipment and their place in a group operated in accordance with a technical condition, or in the planned-preventive system;

- estimated risk of damage;

- availability of spare parts from the manufacturer, time and the expected cost of delivery;

- possibility to apply replacements; 
The application of probability elements in optimizing supply of spare parts... Zastosowanie elementów probabilistyki w optymalizacji wielkości zapasów...

- possibility of repair (regeneration), and the quality of supplied components;

- the forecast loss of current operations in the event of unavailability of material;

- inventory capabilities of the organizational unit.

\section{Summary}

Despite the determination of the above directions of action, in many factories and companies, the safety stock margin of spare parts usually exceeds the necessary minimum. This is mainly due to the intuitive desire to carry out the tasks on time and completely eliminate delays of technical equipment. Research conducted in this direction shows, however, that the costs of stocks of spare parts often exceed $50 \%$ of the total maintenance costs in industrial enterprises. The very cost of the parts constitutes $40 \%$ to $70 \%$ of the total cost of the repair and the expenditure incurred in the purchase and maintenance of the parts until their installation in devices significantly increase manufacturing and operating costs.

On the other hand, $50 \%$ of the total delays of machinery and equipment in various industrial branches is caused by the lack of availability of parts in stock. ${ }^{15}$.

Modern systems which support exploitation are essentially linked with the movement or inactivity of supply measures increasingly implement mathematical models and elements of probability calculus. However, they need to be provided with correct, complete and well-interpreted data. Effective management of the size of the spare parts inventory is an organizational problem in many companies. Implementing innovative solutions does not always give the desired results. ${ }^{16}$ These activities are consistent with the essence of the logistics system, which in addition to the "core material" also includes in its structure consolidated information and financial streams. The aim of the applications of computer science in exploitation systems and logistics processes is to optimize in terms of the quantity and value, that is to lower the cost of essential activities (production, equipment exploitation...), increase the efficiency of manufacturing operations (manufacturing, services, training ...) and reduce the size of frozen capital (e.g. the size of kept stocks). The optimal planning method of the stock size of spare parts and subassemblies for aviation technology, taking into account conditions arising from the intensity of the operation, should therefore increase the availability of parts and subassemblies, which in the long run will increase the level of technical efficiency of equipment while minimizing the costs of expenses.

\section{References}

[1] Cieciura M., Zacharski J.: Metody probabilistyczne w ujęciu praktycznym, Warszawa 2007

[2] Grondys K.: Klasyfikacja zapasu części zamiennych, Logistyka 5/2013, Instytut Logistyki i Magazynowania, Poznań 2013.

[3] Instrukcja stużby inżynieryjno - lotniczej lotnictwa Sit Zbrojnych RP, Bydgoszcz 2017,

[4] Kisperska-Moroń D., Krzyżaniak St. (red): Logistyka, Poznań 2009.

${ }^{15}$ Grondys, 2013: 75

${ }^{16}$ Majewski, 2008: 21, 140-145 
[5] Krawczyk St.: Logistyka. Teoria i praktyka, t1, t2, Warszawa 2011.

[6] Krzyżaniak St.: Podstawy zarzązania zapasami w przykładach, Poznań 2005.

[7] Macha E.: Niezawodność maszyn, Politechnika Opolska, skrypt nr 237, Opole 2001.

[8] Majewski J.: Informatyka dla logistyki, Poznań 2008

[9] Mączyński W. Zarządzanie częściami zamiennymi, Inżynieria i utrzymanie ruchu 1/2013.

[10] Mesjasz-Lech A.: Wybrane problemy zastosowania metod statystycznych $w$ analizie popytu $w$ przedsiębiorstwie, Logistyka 5/2011.

[11] Sarjusz - Wolski Z.: Sterowanie zapasami w przedsiębiorstwie, Warszawa 2000

[12] Zbroja T.: Zarzadzanie produkcja i ustugami, www.ioz.pwr.wroc.pl.

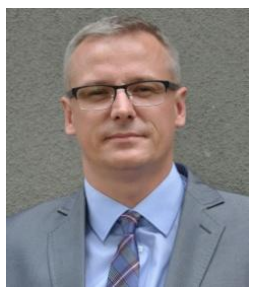

Col. Norbert Grzesik, Aviation Faculty, Polish Air Force Academy in Dęblin. He received the M.S. degree in aviation and mechatronics engineering from Military University of Technology, Warsaw, Poland, in 1999 and the Ph.D. degree in machines construction and maintenance from Rzeszow University of Technology, Rzeszow, Poland, in 2006. Habilitation in Air Force Institute of Technology in 2016. His specialization is using fuzzy expert inference systems application in aircraft (military and civilian) on-board reliability and efficiency evaluation systems. He is a certified armament and avionics maintenance engineer of many types of aircraft (F-16, MiG-29, Su-22, Ts-11, Mi-2, W-3W and others). Member of European Society for Fuzzy Logic and Technology (EUSFLAT), Aviation Scientific Council (scientific cooperation between Polish Air Force Academy in Deblin and Air Force Institute of Technology in Warsaw) and Polish Scientific and Technical Exploitation Society.

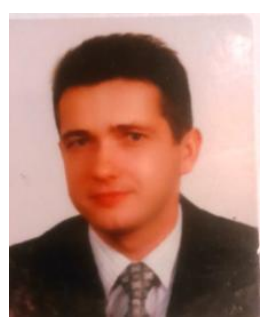

Maj. Tomasz Iwan, 41. Air Training Base in Dęblin, deputy chairman of the team for implementation in the military of modern aviation equipment, experienced specialist in the field of technical support for operation, technical reliability as well as certified advisor in the field of road transport of dangerous goods. He received the M.Sc. in 2000 from the Faculty of Mechanical Engineering at the Military University of Technology, Warsaw, Poland. The beginning of scientific work is a series of research in the field of materials engineering, in particular the prospects for the use of composite materials under construction and machine operation. The current area of interest is also the optimization of the management processes of the operation of aviation equipment and increase the efficiency of material and technical management in military units and institutions. 
The application of probability elements in optimizing supply of spare parts... Zastosowanie elementów probabilistyki w optymalizacji wielkości zapasów...

\section{ZASTOSOWANIE ELEMENTÓW PROBABILISTYKI W OPTYMALIZACJI WIELKOŚCI ZAPASÓW CZĘŚCI ZAMIENNYCH I PODZESPOLÓW W LOTNICTWIE}

\section{Wstęp}

Złożoność systemów eksploatacji w różnych branżach, przedsiębiorstwach $\mathrm{i}$ instytucjach jest powiązana $\mathrm{z}$ dużym natężeniem przepływu środków materiałowych, podzespołów i gotowych wyrobów. Ściśle zsynchronizowane z nimi są zawsze strumienie usług, informacji i środków finansowych w otoczeniu infrastruktury technicznej.

Niezwykle charakterystyczną, ale też i ważną grupę urządzeń technicznych stanowi sprzęt techniki lotniczej. Przyjmowane założenia wynikające $\mathrm{z}$ obowiązującego planowo - zapobiegawczego systemu eksploatacji mają na celu zapewnienie maksymalnego poziomu bezpieczeństwa wykonania operacji lotniczych a jednocześnie dużą dostępność (zdatność do lotu) statków powietrznych ${ }^{17}$. W związku z tym wydawać by się mogło, że należy podjąć wszelkie możliwe środki, ażeby zminimalizować ryzyko braków magazynowych części zamiennych (agregatów) do samolotów i śmigłowców, a tym samym uniknąć nadmiernych ich przestojów. Specyficzną cechą podzespołów i wszelkich technicznych środków materiałowych do tego typu sprzętu jest oczywiście ich wartość nabycia oraz „zamrożenie” istotnego kapitału w przypadku braku zapotrzebowania na powyższy asortyment. Awaryjność, a zatem też i „popyt” na części zamienne mogą być niejednokrotnie trudne do zdefiniowania, ponieważ częstotliwość występowania uszkodzeń jest zmienną losową. Należy również wspomnieć, że stopień intensywności zużywania się poszczególnych części i podzespołów jest zwykle niejednorodny, a tym samym nieprzewidywalny. Dodatkowo długotrwałe przechowywanie lotniczych części zamiennych powoduje niestety stopniowe obniżanie się ich własności techniczno-eksploatacyjnych pod wpływem m.in. starzenia naturalnego materiałów konstrukcyjnych oraz rozkalibrowania ustawień parametrów użytkowych. Tak więc prognozowanie zapotrzebowania dla większości grup części zamiennych jest skomplikowane i wymaga głębokiej analizy wielu czynników takich jak: intensywność eksploatacji sprzętu lotniczego, struktura wiekowa oraz wielkość i charakter zapotrzebowania w poprzednich przedziałach czasu.

Jako rzeczywisty przykład przedstawiony został wykres rozchodów i przychodów magazynowych pewnej grupy części zamiennych w przeciągu rocznego okresu rozliczeniowego - Rys 1 .

W przedziale czasu A widoczne są pewne obroty materiałowe bez wyraźnej systematyczności, po czym następuje okres, w którym nie występują żadne ruchy magazynowe.

\footnotetext{
${ }^{17}$ Zob. Instrukcja stużby inżynieryjno - lotniczej lotnictwa Sit Zbrojnych RP, Bydgoszcz 2017
} 
Obszar B rozpoczyna się szybkim zużyciem całego zapasu części zamiennych, po czym następują pewne cykle odtwarzania i zużywania zapasu. W obszarze $\mathrm{C}$ odnotowano natomiast drastyczny wzrost poziomu zapasów podyktowany prawdopodobnie zwrotem wcześniej pobranych i niewykorzystanych części. Sytuacja taka może mieć miejsce w wielu podmiotach, ponieważ części pobierane $\mathrm{z}$ magazynu pozostają często poza kontrolą i rzeczywisty ich stan w systemie eksploatacji nie jest znany. Ujawnienie nadwyżek następuje zwykle w wyniku późniejszych inwentaryzacji i po powtórnym przyjęciu asortymentu do magazynu ${ }^{18}$.

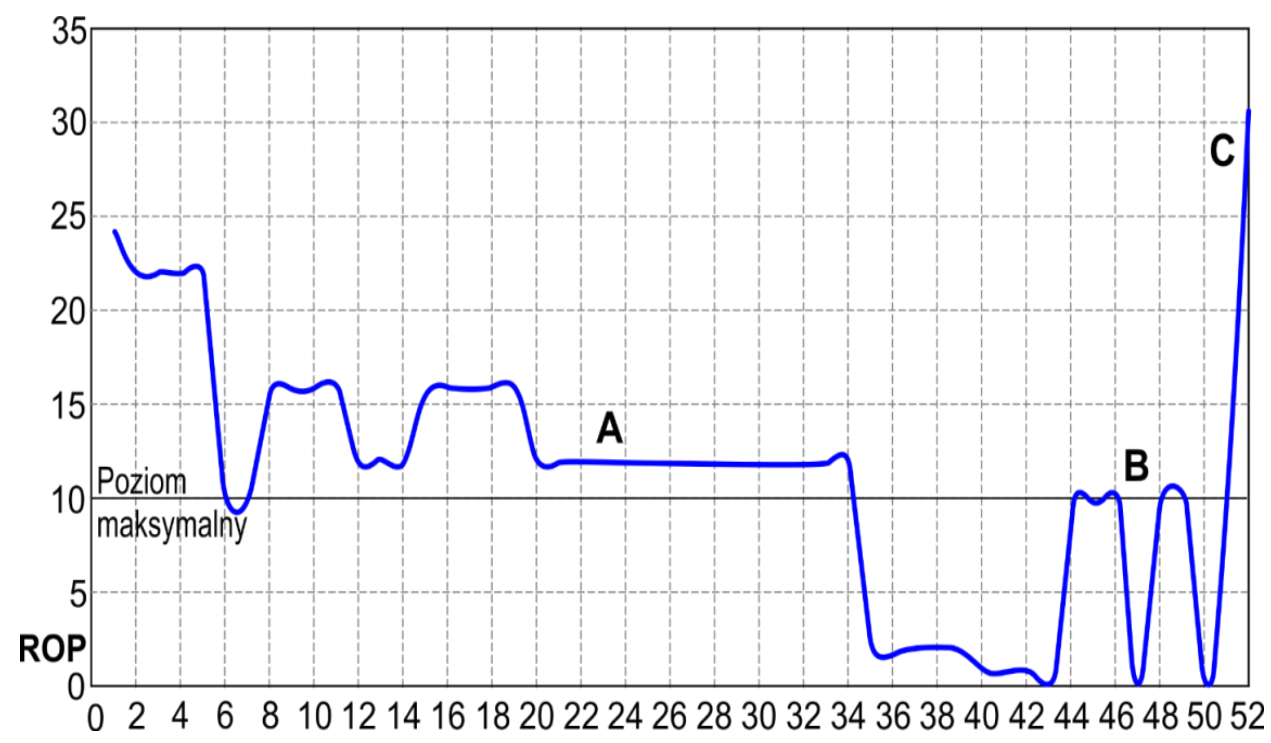

Rys. 1 Przebieg rzeczywistego stanu magazynowego dla wybranego asortymentu Źródło: Mączyński W.[9].

\section{Struktura zapasów materiałowych części zamiennych}

Zapasy części zamiennych znajdując swoje usytuowanie w systemie eksploatacji sprzętu technicznego mogą wykazywać duży obrót w przyjętym okresie rozliczeniowym, ale mogą również istnieć pewne grupy asortymentowe, na które popyt jest znikomy lub wręcz nie istnieje. Uproszczoną strukturę modelową zapasu, która znajduje zastosowanie również w przypadku części zamiennych zamieszczono na Rys 2.

18 Mączyński, 2013: 51-53 
The application of probability elements in optimizing supply of spare parts... Zastosowanie elementów probabilistyki w optymalizacji wielkości zapasów...

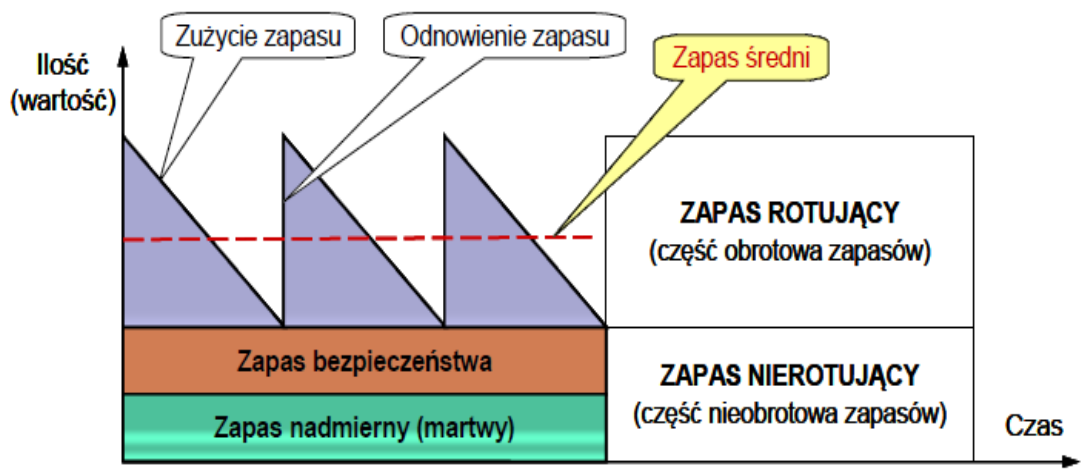

Rys. 2 Struktura modelowa zapasów części zamiennych Źródto: Zbroja T. [12].

\section{Klasyfikacje części zamiennych w prognozowaniu popytu}

Zapotrzebowanie niezależne na części zamienne ma charakter losowy i podlega zwykle prognozowaniu na podstawie danych $\mathrm{z}$ okresów poprzednich. W związku z tym podczas planowania zaopatrzenia, jedną z bardziej efektywnych metod umożliwiających późniejsze sterowanie poziomem i strukturą asortymentową jest klasyfikacja ABC podziału technicznych środków materiałowych na trzy grupy:

- grupa A - zapasy części „cennych” (vital few), stanowiące jedynie 5 $\div 20 \%$ liczebności asortymentowej zapasów, ale mające znaczny udział w wartości, sięgający $75 \div 80 \%$; grupę tę, o wysokiej wartości i (lub) dużym udziale w kosztach materiałowych ogółem, należy traktować ze szczególną uwagą w zakresie: właściwego zarządzania poziomami zapasów. W skład tej grupy mogą wchodzić często części specjalne niewymienne $\mathrm{z}$ innymi i o najdłuższym czasie dostawy,

- grupa B - części i materiały mające udział w wysokości $15 \div 20 \%$ zarówno $\mathrm{w}$ liczebności asortymentowej, jak i ich wartości (grupa środkowa). W skład tej grupy często wchodzą części standardowe, produkowane przez wielu producentów a mające zastosowanie $\mathrm{w}$ różnych typach sprzętu,

- grupa $\mathrm{C}$ - materiały o charakterze masowym (trivial many), mające największy udział w liczebności asortymentowej $(60 \div 80 \%)$ i bardzo niski udział w wartości (około 5\%). W skład tej grupy mogą wchodzą zwykle materiały eksploatacyjne łatwo dostępne i materiały jednorazowego użytku wspólne dla wielu maszyn i urządzen ${ }^{19}$

\footnotetext{
${ }^{19}$ Krzyżaniak, 2005: 20-25
} 
Proporcje w poszczególnych grupach zapasów układają się w przybliżeniu w taki sposób, że około $20 \%$ pozycji stanowi aż $80 \%$ w ujęciu wartościowym, przez co metoda $\mathrm{ABC}$ określana jest również jako „,80/20” lub też zasada Vilfreda Pareto $^{20}$.

W odniesieniu do grupy A racjonalne przesłanki wskazują na zasadność zastosowania ostrego reżimu przy składaniu zamówień na części, podczas gdy w odniesieniu do pozostałych materiałów, zwłaszcza grupy C („najtańszej”), można sobie pozwolić na swobodniejsze reguły zamawiania i tworzenia zapasów.

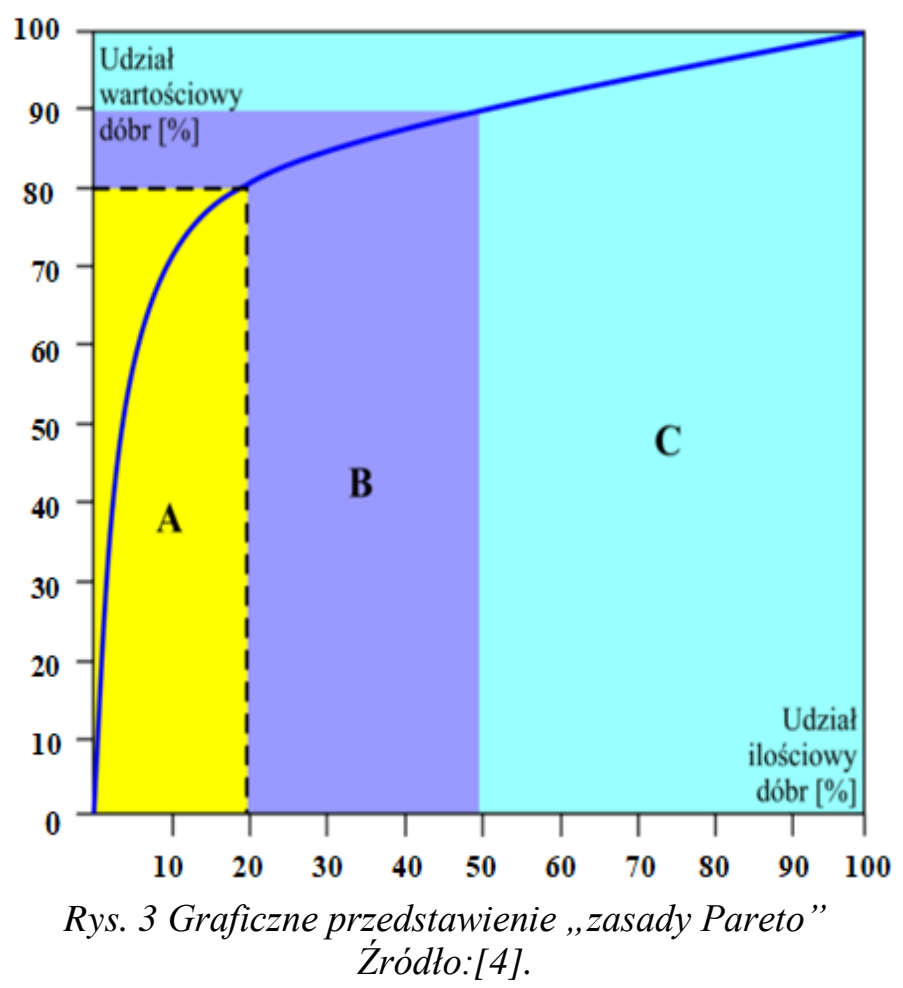

Dane statystyczne z wcześniejszych okresów służą również do określenia regularności i zmienności danych o popycie na asortyment. Dlatego też efektywnym uzupełnieniem zasady „80/20” jest metoda XYZ odnosząca się do regularności popytu na zapas $\mathrm{W}$ założonym okresie rozliczeniowym, a poszczególne rodzaje materiałów zostają podzielone na trzy grupy:

- grupa X - części i podzespoły, na które występuje regularne zapotrzebowanie (dobrze rotujące), $\mathrm{z}$ względnie dużą dokładnością prognozowania zapotrzebowania;

${ }^{20}$ Kisperska-Moroń, Krzyżaniak (red) 2009: 67-68 
The application of probability elements in optimizing supply of spare parts... Zastosowanie elementów probabilistyki w optymalizacji wielkości zapasów...

- grupa Y - części i podzespoły, na które zapotrzebowanie ma charakter sezonowy lub zgodny z określonym trendem (średnio rotujące), ze średnią dokładnością prognozowania zapotrzebowania;

- grupa Z - materiały o bardzo nieregularnym zapotrzebowaniu (słabo rotujące) i niskiej dokładności prognozy tego zapotrzebowania.

W teorii sterowania zapasami części zamiennych do techniki lotniczej, na szczeblu jednostek wojskowych zasadne może być zastosowanie syntezy obydwu metod, przez uzyskać można 9 kombinacji pozwalających na wyodrębnienie kluczowych grup materiałów ${ }^{21}$.

Połączenie analizy ABC i XYZ umożliwia zróżnicowane podejście do zarządzania zapasami poszczególnych pozycji, od najbardziej znaczących wartościowo i regularnie rotujących (prognozowalnych) - grupa $\mathbf{A X}$, do mało znaczących wartościowo i sprzedawanych sporadycznie, - grupa CZ. Dlatego też przy zarządzaniu wielkością zapasów zasadnym jest skupienie głównego wysiłku na dokładnym planowaniu zamówień $\mathrm{w}$ grupach towarów o najwyższej wartości i największej precyzji prognozowania zapotrzebowania (grupy AX, BX i AY).

Tab. 1 Zestawienie klasyfikacji ABC i XYZ dla części zamiennych

\begin{tabular}{|c|c|c|c|c|}
\hline & \multicolumn{3}{|c|}{ Wartość zapasu } \\
\hline & & $\mathbf{A}$ & B & $\mathbf{C}$ \\
\hline \multirow{3}{*}{ 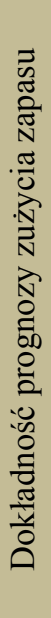 } & $\mathbf{X}$ & $\begin{array}{c}\text { wysoki poziom wartości } \\
\text { zużycia, wysoka } \\
\text { doktadność prognozy } \\
\text { zapotrzebowania } \\
\text { (wahania poniżej 20\%) }\end{array}$ & $\begin{array}{c}\text { średni poziom wartości } \\
\text { zużycia, wysoka } \\
\text { doktadność prognozy } \\
\text { zapotrzebowania } \\
\text { (wahania poniżej 20\%) }\end{array}$ & $\begin{array}{l}\text { niski poziom wartości } \\
\text { zużycia, wysoka } \\
\text { dokładność prognozy } \\
\text { zapotrzebowania } \\
\text { (wahania poniżej 20\%) }\end{array}$ \\
\hline & $\mathbf{Y}$ & $\begin{array}{c}\text { wysoki poziom wartości } \\
\text { zużycia, średnia } \\
\text { dokladność prognozy } \\
\text { zapotrzebowania } \\
\text { (wahania } 20-50 \% \text { ) }\end{array}$ & $\begin{array}{c}\text { średni poziom wartości } \\
\text { zużycia, średnia } \\
\text { dokładność prognozy } \\
\text { zapotrzebowania } \\
\text { (wahania } 20-50 \% \text { ) }\end{array}$ & $\begin{array}{l}\text { niski poziom wartości } \\
\text { zużycia, średnia } \\
\text { dokładność prognozy } \\
\text { zapotrzebowania } \\
\text { (wahania } 20-50 \%)\end{array}$ \\
\hline & $\mathbf{Z}$ & $\begin{array}{c}\text { wysoki poziom } \\
\text { wartości zużycia, niska } \\
\text { dokładność prognozy } \\
\text { zapotrzebowania } \\
\text { (wahania powyżej } 50 \% \text { ) }\end{array}$ & $\begin{array}{c}\text { średni poziom wartości } \\
\text { zużycia, niska } \\
\text { dokładność prognozy } \\
\text { (wahania powyżej 50\%) }\end{array}$ & $\begin{array}{c}\text { niski poziom wartości, } \\
\text { zużycia, niska } \\
\text { dokładność prognozy } \\
\text { (wahania powyżej 50\%) }\end{array}$ \\
\hline
\end{tabular}

Źródto: Opracowanie wtasne

W celu zobrazowania skomplikowanej i wieloaspektowej problematyki planowania potrzeb materiałowych do techniki lotniczej, poniżej zamieszczono $\mathrm{w}$ formie graficznej dane dotyczące ilości (Rys. 4) i wartości (Rys. 5) zmagazynowanych części zamiennych do samolotów i śmigłowców w latach poprzednich na przykładzie wybranej jednostki wojskowej ${ }^{22}$.

${ }^{21}$ Krawczyk, t. 2, 2011: 194-198

22 Dane szczegółowe dostępne $\mathrm{u}$ autora 


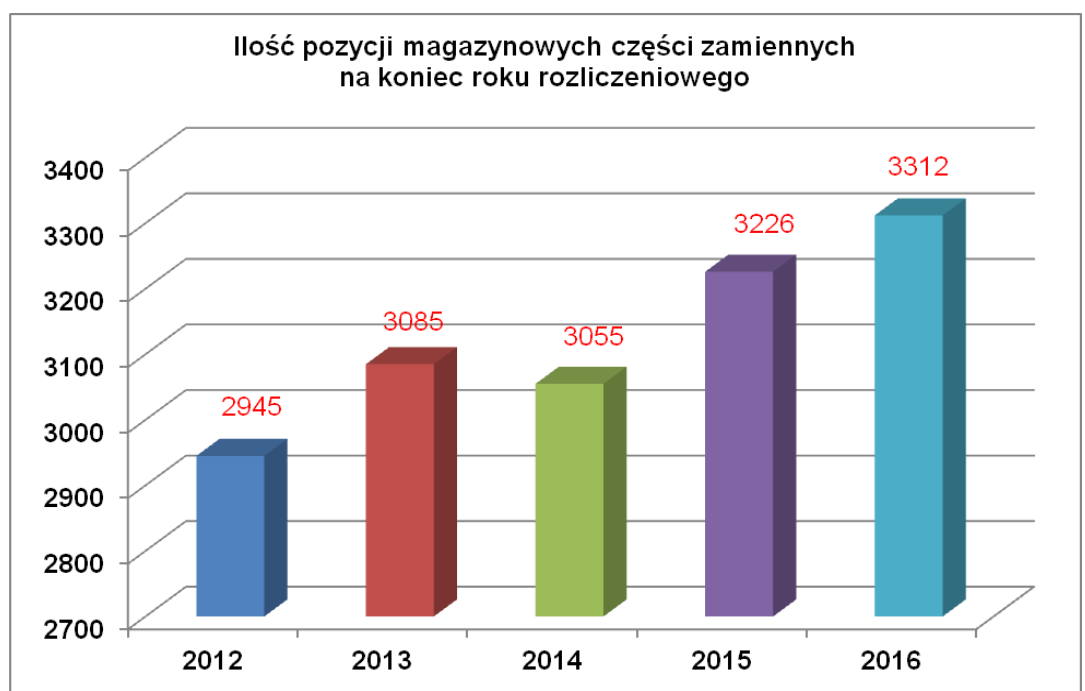

Rys. 4 Zestawienie ilościowe części zamiennych w latach $2012 \div 2016$ Źródto: Opracowanie własne

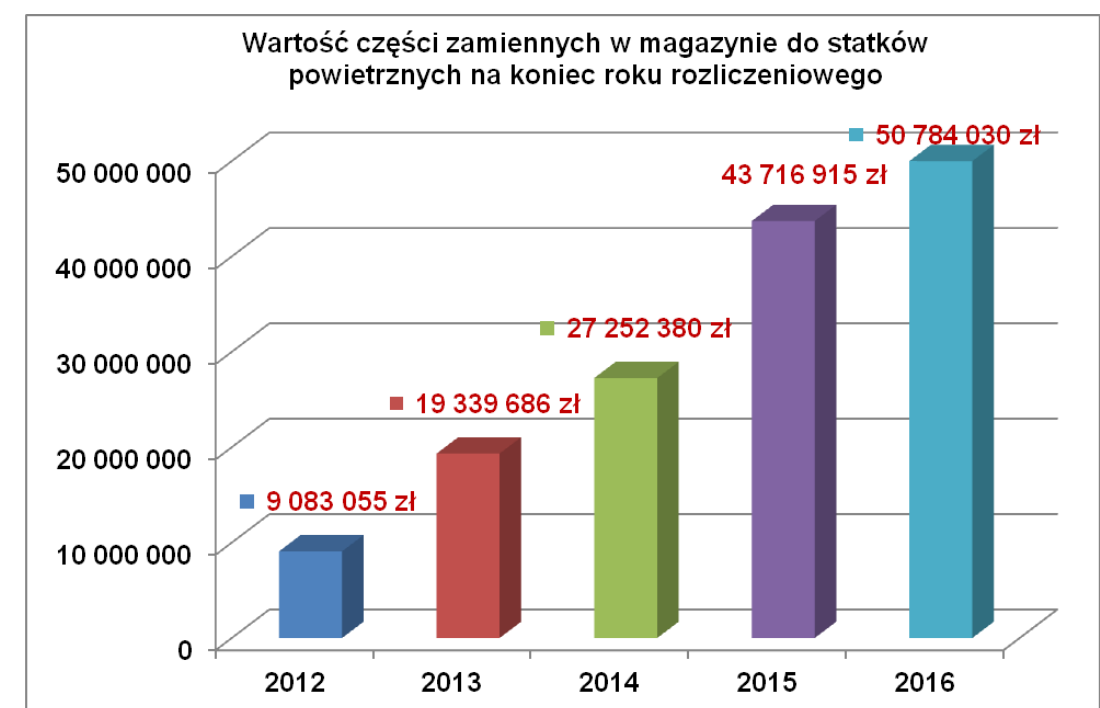

Rys. 5 Zestawienie wartości części zamiennych do statków powietrznych w magazynie. Źródło: Opracowanie własne

Utrudnienia przy planowaniu potrzeb na części zamienne do techniki lotniczej potwierdzają graficzne zależności pomiędzy ilością ogólną pozycji magazynowych (typów części i podzespołów) a ich przychodem i rozchodem w latach 2014 oraz 2015 (Rys. 6). Na Rys. 7 zestawiono analogiczne ujęcie wartościowe przechowywanych części zamiennych z wartością przychodów i rozchodów. 
The application of probability elements in optimizing supply of spare parts... Zastosowanie elementów probabilistyki w optymalizacji wielkości zapasów...

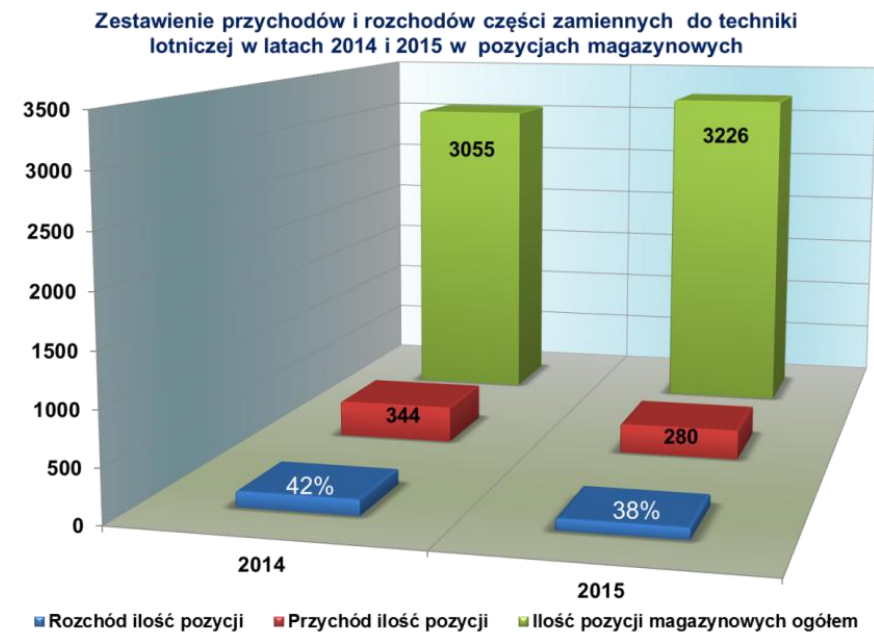

Rys. 6 Zestawienie ilościowe obrotów części zamiennych w latach 2014 i 2015 Źródło opracowanie własne na podstawie programów ewidencyjnych MAG-MAT i ZWSI RON

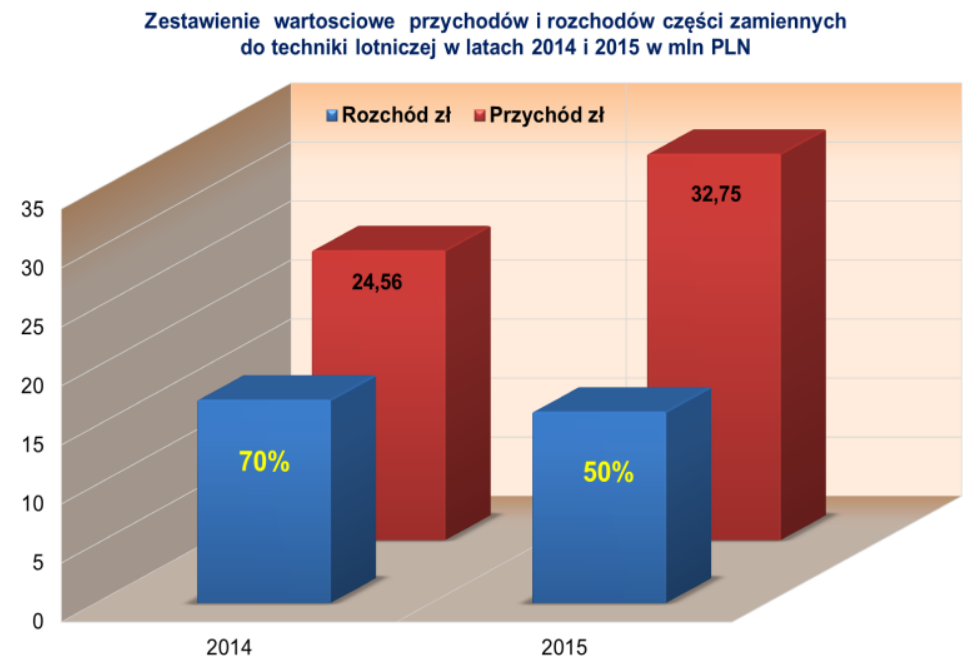

Rys. 7 Zestawienie wartościowe obrotów części zamiennych w latach 2014 i 2015 Źródto opracowanie własne na podstawie programów ewidencyjnych MAG-MAT $i$ ZWSI RON

$\mathrm{Na}$ przykładzie przedstawionych danych o przyjęciach i wydaniach części zamiennych z magazynu jednostki w latach poprzednich, jak też po dokonaniu analizy struktury ilościowej i wartościowej gromadzonych i wydawanych zapasów należy stwierdzić, że wartość aktywów magazynowych sukcesywnie wzrasta. Jest to m.in. efektem mniejszego strumienia odpływu części lotniczych z magazynu w stosunku do ich przychodu. 
Przeszacowanie wielkości zamówień $\mathrm{w}$ stosunku do poziomu realnych potrzeb zarówno w ujęciu ilościowym jak i wartościowym nie jest zjawiskiem rzadkim i występuje również w innych branżach, takich jak motoryzacyjna czy budowlana. Jednakże biorąc pod uwagę rozmiar różnic, uzasadnione byłoby zmniejszenie dysproporcji pomiędzy podażą, a popytem na zapas części lotniczych czyli optymalizacja całokształtu gospodarki magazynowej.

\section{Elementy rachunku prawdopodobieństwa $w$ sterowaniu zapasami}

Ryzyko w zarządzaniu eksploatacją jest zagadnieniem ściśle powiązanym z teorią zarządzania zapasami, ponieważ nie jest możliwe przewidzenie wszystkich okoliczności wpływających na niezależne zapotrzebowanie na części i podzespoły rozłączne. W przypadku maszyn i urządzeń popyt na części zamienne i materiały eksploatacyjne będzie uzależniony od niezawodności technicznej, która jest wielkością charakteryzującą zdolność sprzętu do spełniania postawionych zadań. Inaczej mówiąc będzie to prawdopodobieństwo, że dany obiekt będzie zdatny (sprawny) w pewnym przedziale czasu $\boldsymbol{T}$ lub że wartości parametrów określających istotne jego właściwości nie przekroczą dopuszczalnych granic $\mathrm{w}$ przyjętych warunkach eksploatacji ${ }^{23}$. Dlatego też niepewność i zmienność zapotrzebowania na materiały będzie inicjowała decyzje w zakresie planowania zapasów i ich późniejszego wykorzystania w działalności eksploatacyjnej. Na rysunkach poniżej zestawiono również porównanie danych dotyczących intensywności eksploatacji statków powietrznych $\mathrm{w}$ latach poprzednich w wybranej lotniczej jednostce wojskowej wyrażonej $\mathrm{w}$ godzinach ogólnego nalotu ${ }^{24}$. Dodatkowo za lata $2014 \div 2016$ zestawione zostały sumaryczne wartości wydanych części zamiennych z magazynu i zabudowanych na statki powietrzne. Z powyższych zestawień wynika, że bezpośrednia korelacja pomiędzy intensywnością eksploatacji sprzętu techniki lotniczej a wartością nowych części i podzespołów zużytych w procesie eksploatacji może mieć bardzo złożony charakter. Należy również zauważyć, że w latach $2014 \div 2016$ występowały sytuacje, że przy względnie niższym nalocie statków powietrznych, wartość nakładów na części zamienne była najwyższa.

Należałoby to interpretować $\mathrm{w}$ ten sposób, że wyższa awaryjność sprzętu utrudniała uzyskanie wysokiej efektywności eksploatacji i generowała większe potrzeby części zamiennych i podzespołów lotniczych. Z drugiej strony, na przykładzie roku 2015 można zauważyć, że względnie duża ilość wymienionych części i podzespołów umożliwiła uzyskanie najwyższego wskaźnika nalotu. Oczywiście awaryjność sprzętu generująca powstanie zapotrzebowania na części zamienne ma charakter zmiennej losowej, która podlega ściśle określonym regułom.

\footnotetext{
${ }^{23}$ Macha: 2001: 7

${ }^{24}$ Dane dostępne u autora
} 
The application of probability elements in optimizing supply of spare parts... Zastosowanie elementów probabilistyki w optymalizacji wielkości zapasów...

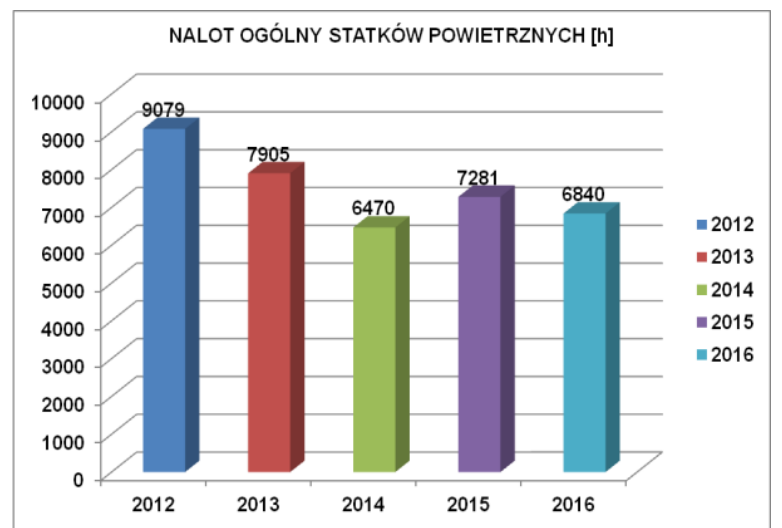

Rys. 8 Zestawienie godzinowe nalotu statków powietrznych z podziatem na lata

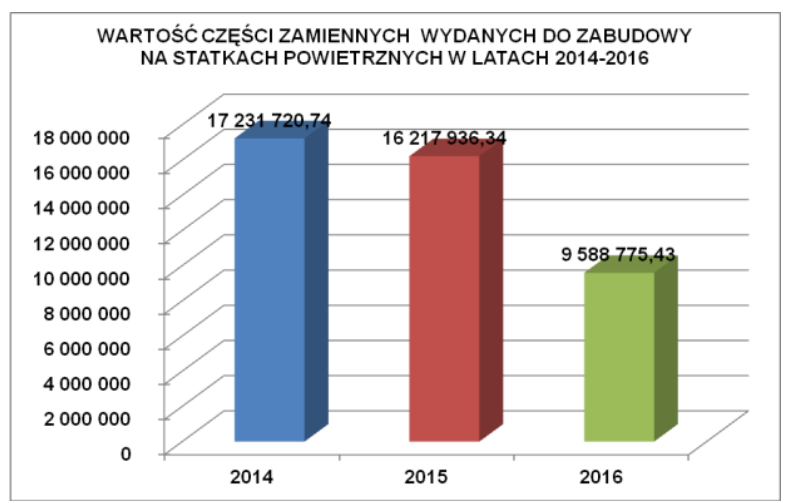

Rys. 9 Zestawienie wartościowe części zamiennych zużytych w procesie eksploatacji techniki lotniczej w poszczególnych latach

W literaturze specjalistycznej i teorii sterowania zapasami dopasowania rozkładu teoretycznego dokonuje się poprzez porównanie wartości średniej zapotrzebowania $\mathrm{z}$ jego odchyleniem standardowym lub wariancją ${ }^{25}$.

Wariancja prognozy zapotrzebowania (popytu) $\sigma_{p}$ jest definiowana jako średnia arytmetyczna kwadratów odchyleń poszczególnych wartości popytu $\boldsymbol{P}_{i}$ od średniej arytmetycznej $\boldsymbol{P}_{s r}$ w rozpatrywanym okresie.

$$
\sigma_{P}^{2}=\frac{1}{n} \sum_{i=1}^{n}\left(P_{i}-P_{\text {sr }}\right)^{2}
$$

Odchylenie standardowe popytu jest definiowane jako pierwiastek kwadratowy $\mathrm{z}$ wariancji popytu.

$$
\sigma_{P}=\sqrt{\sigma_{P}^{2}}=\sqrt{\frac{1}{n} \sum_{i=1}^{n}\left(P_{i}-P_{\mathrm{sr}}\right)^{2}}
$$

${ }^{25}$ Por. Mesjasz-Lech, 2011:1161 
Bardzo przydatnym wskaźnikiem statystycznym obrazującym zmienność zapotrzebowania na zapas części jest współczynnik zmienności względnej, który jest wyrażonym procentowo odniesieniem odchylenia standardowego $\sigma_{p}$ popytu do jego wartości średniej $\boldsymbol{P}_{s \boldsymbol{r}}$

$$
\Delta_{p}=\frac{\sigma_{p}}{P_{\mathrm{s} r}} * 100 \%
$$

Określa on $\mathrm{w}$ prosty sposób jakim wahaniom ulegał popyt $\mathrm{w}$ stosunku do jego wartości średniej w minionym okresie. Dlatego też w celu uproszczenia interpretacji powyższych pojęć, średni popyt na części zamienne warto zdefiniować oznaczeniem $\boldsymbol{P}_{\dot{s} r \pm} \boldsymbol{\sigma}_{p}$ [wyrażenie w jednostkach miary] lub $\boldsymbol{P}_{\dot{s} r} \boldsymbol{\Delta}_{p}$ [wyrażenie w \%]. Wartość powyższego współczynnika wskazuje ponadto na szybkość rotacji i ułatwia zakwalifikowanie towaru do jednej z grup materiałowych $\mathrm{X}, \mathrm{Y}$ lub Z.

W planowaniu zapasów technicznych środków materiałowych powszechnie stosowane są trzy podstawowe rozkłady prawdopodobieństwa zapotrzebowania na techniczne środki materiałowe ${ }^{26}$.

Rozkład normalny - znajduje częste zastosowanie w opisie popytu na pozycje magazynowe szybko rotujące, zużywane $w$ masowych ilościach i klasyfikowane $\mathrm{w}$ grupie $\mathrm{X}$, a także czasami $\mathrm{w}$ grupie $\mathrm{Y}$ - przy większych wartościach współczynnika zmienności popytu ${ }^{27}$. Dlatego też $\mathrm{w}$ teorii sterowania zapasami przyjmuje się, że popyt na określona pozycję asortymentową podlega rozkładowi normalnemu, jeżeli wartość średnia zapotrzebowania jest znacznie większa od kwadratu odchylenia standardowego (wariancji).

Rozkładem Poissona (skokowym) opisuje się prawdopodobieństwo zajścia zdarzeń stosunkowo rzadkich i niezależnych od siebie przy występowaniu dużej ilości doświadczeń. Będzie on więc odwzorowywał popyt na pozycje magazynowe wolno rotujące, wyrażone całkowitymi nieujemnymi liczbami sztuk lub kompletów. Zastosowanie rozkładu Poissona jest możliwe, gdy wartość średnia popytu $\boldsymbol{P}_{s r}$ jest w przybliżeniu równa jego wariancji, czyli spełniona jest zależność:

Rozkład wykładniczy jest trzecią odmianą zależności stochastycznych również stosowaną $\mathrm{W}$ zarządzaniu poziomem zapasów logistycznych. Ma on zwykle zastosowanie w planowaniu zapasów materiałów wolno rotujących (o małych wartościach zużycia). Przy jego pomocy można również opisywać czas pracy urządzeń technicznych pomiędzy dwoma kolejnymi uszkodzeniami, co z kolei ma swoje odzwierciedlenie w zapotrzebowaniu na części zmienne. Popyt na zapas daje się opisać rozkładem wykładniczym, jeżeli odchylenie standardowe oscyluje wokół wartości średniej.

\footnotetext{
${ }^{26}$ Zob. Cieciura, Zacharski, 2007:184-186

${ }^{27}$ Krzyżaniak, 2009: Logistyka 1/2009
} 
The application of probability elements in optimizing supply of spare parts... Zastosowanie elementów probabilistyki w optymalizacji wielkości zapasów...

Syntetyczne zestawienie stosowanych w teorii zapasów rozkładów prawdopodobieństw oraz warunki zastosowań zestawiono w tabeli 2.

Tab. 1 Kryteria doboru i zastosowanie rozkładów prawdopodobieństwa

\begin{tabular}{|c|c|c|c|c|}
\hline \multicolumn{1}{|c|}{} & \multicolumn{1}{|c|}{$\begin{array}{c}\text { Zastosowanie } \\
\text { Typ rozkładu }\end{array}$} & $\begin{array}{c}\text { Zależności } \\
\text { pomiędzy } \\
\text { parametrami } \\
\text { rozkładu }\end{array}$ & $\begin{array}{c}\text { Wartość } \\
\text { współczynnika } \\
\text { zmienności } \\
\text { popytu }\end{array}$ & $\begin{array}{c}\text { Grupa } \\
\text { materiałowa } \\
\text { według } \\
\text { klasyfikacji } \\
\text { XYZ }\end{array}$ \\
\hline Normalny & $\begin{array}{c}\text { Towary zużywanie } \\
\text { w dużych ilościach, } \\
\text { szybko rotujące }\end{array}$ & $P_{\text {śr }}>\sigma_{\mathrm{p}}^{2}$ & $\Delta_{\mathrm{p}}<<100 \%$ & $\mathbf{X}$ lub Y \\
\hline Poissona & $\begin{array}{c}\text { Towary rzadko } \\
\text { poszukiwane }\end{array}$ & $P_{\text {śr }} \approx \sigma_{\mathrm{p}}^{2}$ & $\Delta_{\mathrm{p}}<100 \%$ & Y lub Z \\
\hline Wykładniczy & $\begin{array}{c}\text { Materiały wolno } \\
\text { rotujące (materiały } \\
\text { o małym zużyciu) }\end{array}$ & $P_{\text {śr }} \approx \sigma_{P}$ & $\Delta_{\mathrm{p}} \rightarrow 100 \%$ & $\mathbf{Z}$ lub Y \\
\hline
\end{tabular}

$P_{s r}-$ wartość średnia popytu, $\sigma_{p}$ - odchylenie standardowe popytu (standardowy btad prognozy) Źródto: opracowanie własne na podstawie [11].

Znajomość podstawowych parametrów rozkładu prawdopodobieństwa $\mathrm{w}$ postaci wartości średniej prognozy popytu oraz odchylenia standardowego umożliwia planowanie wielkości zapasów części zamiennych. Im większe przewidywane potrzeby oraz standardowy błąd prognozy (odchylenie standardowe), tym większy musi być poziom zapasu bezpieczeństwa. Wielkość utrzymywanej rezerwy będzie również uzależniona od przyjętego poziomu obsługi potrzeb. W literaturze specjalistycznej stosowane jest równolegle pojęcie współczynnika ufności, który jest definiowany jako prawdopodobieństwo, że popyt na materiały nie okaże się większy od zakładanego (od średniej prognozy popytu). Prawdopodobieństwo zdarzenia przeciwnego polegającego na wystąpieniu zapotrzebowania większego od przeciętnego określane jest mianem wspólczynnika ryzyka ${ }^{28}$.

Uzależnienie wielkości zapasu bezpieczeństwa $\boldsymbol{Q}_{Z}(\boldsymbol{Z B})$ od założonego poziomu obsługi odbywa się z wykorzystaniem tzw. współczynnika bezpieczeństwa $\boldsymbol{\omega}$, którego wartość jest podporządkowana konkretnemu typowi rozkładu prawdopodobieństwa.

$$
Z B=\omega * \sigma_{P T}
$$

gdzie: $\sigma_{P T}$ - odchylenie standardowe zapotrzebowania (popytu na zapas) w cyklu uzupełnienia zapasu (w ogólnym przypadku standardowy błąd prognozy popytu).

W prognozowaniu zapotrzebowania na zapas, zastosowanie modeli matematycznych i elementów statystyki wydaje się nieodzowne. Kluczową kwestią jest dobór odpowiedniego modelu matematycznego, który odwzoruje przestrzeń losową w sposób najbliższy rzeczywistości logistycznej.

${ }^{28}$ Zob. Sarjusz-Wolski: 2000: 38 
W celu prawidłowego ukształtowania zapasu bezpieczeństwa (zabezpieczającego), niezbędne jest poznanie rozkładu popytu w ogólnym cyklu uzupełniania zapasu. Elementy statystyki matematycznej umożliwiają skuteczną identyfikację trendów oraz elementów sezonowości popytu na materiały a niepewność w planowaniu potrzeb materiałowych można zasadniczo zredukować do odchyleń przypadkowych (niemożliwych do wyeliminowania lub nawet niejednokrotnie do przewidzenia).

Należy zatem podsumować, że im większa dokładność prognozy przyszłego popytu, tym mniejszy zapas zabezpieczający części zamiennych jest konieczny do zapewnienia pożądanego poziomu obsługi klienta, a tym samym również niższe koszty utrzymywania zapasów ${ }^{29}$.

\section{Istota oraz założenia metod optymalizacji w planowaniu i organizacji eksploatacji}

Jak już zasygnalizowano, w ustalaniu poziomu obsługi potrzeb i związanego z nim zapasu bezpieczeństwa części zamiennych wykorzystywany jest często rachunek prawdopodobieństwa ${ }^{30}$. Modelowy schemat ustalania poziomu zapasów został przedstawiony na 0 . Założenie poziomu obsługi klienta na poziomie np. 98\% (prawdopodobieństwo zaspokojenia potrzeb części zamiennych w danym cyklu odtwarzania zapasów wyniesie 0,98) oznacza, że ryzyko wystąpienia niedoboru zapasu wyniesie tylko $2 \%$. Można oczywiście jeszcze zwiększyć prawdopodobieństwo niewystąpienia braku zapasu (symboliczne przesunięcie podpory w stronę prawą), ale jednocześnie, aby belka pozostawała w równowadze, należy zwiększyć poziom zapasu bezpieczeństwa, co z kolei będzie skutkowało zwiększeniem reakcji pionowej $\boldsymbol{R}$ podpory, a więc i podniesieniem sumarycznych kosztów zapasów.

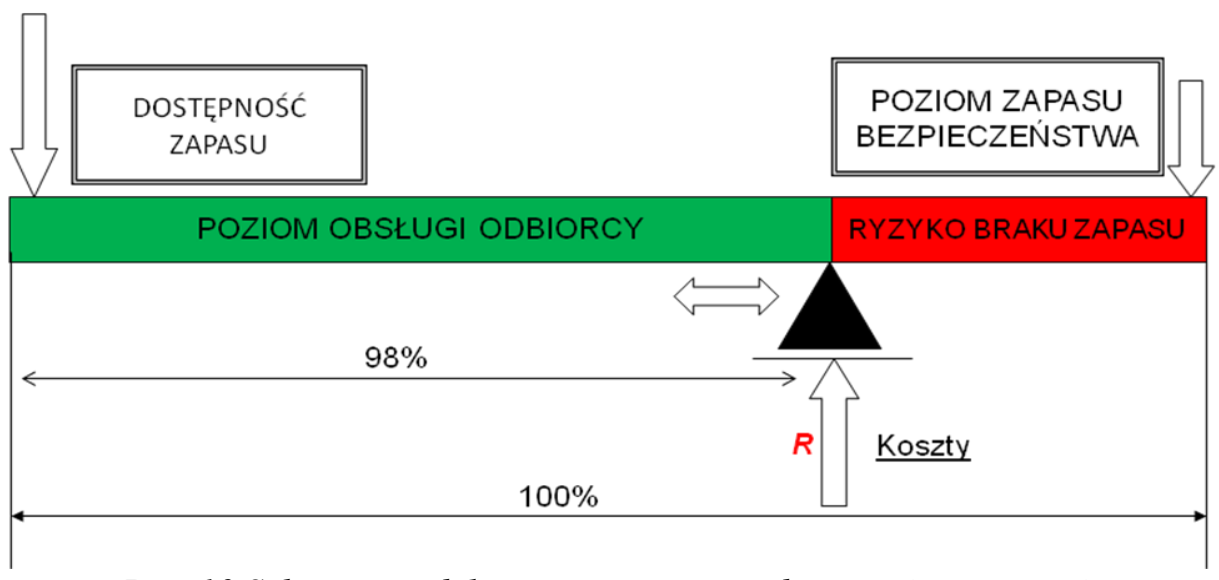

Rys. 10 Schemat modelowy procesu gospodarowania zapasami.

Źródto: Opracowanie własne na podstawie [4] [6].

${ }^{29}$ Krzyżaniak, 2005: 43

30 Kisperska-Moroń, Krzyżaniak (red), 2009: 113 
The application of probability elements in optimizing supply of spare parts... Zastosowanie elementów probabilistyki w optymalizacji wielkości zapasów...

Przykładowymi wskaźnikami służącymi optymalizacji zapasów części zamiennych mogą być zatem:

- ogólna wartość magazynu,

- liczba postojów jednostek sprzętowych spowodowanych brakami części,

- liczba pozycji magazynowych $\mathrm{z}$ podziałem na wolnobieżne/szybkobieżne (zgodnie $\mathrm{z}$ metodą $\mathrm{ABC}$ ),

- intensywność ruchów magazynowych (zgodnie z analizą XYZ),

- redukcja stanów magazynowych.

W związku z powyższym, w celu osiągnięcia wyznaczonych celów strategicznych, zasadnym byłoby przyjęcie ogólnego algorytmu postępowania optymalizacyjnego, który powinien zawierać następujące fazy:

- analiza usterek sprzętu lotniczego (wskaźnika sprawności technicznej);

- określenie zapotrzebowania na części zamienne dla każdego typu sprzętu;

- ocena poziomu posiadanych zapasów części zamiennych do samolotów i śmigłowców;

- oszacowanie ryzyka i porównanie kosztów niedoboru części z kosztami utrzymania zapasów;

- eliminacja nieużywanych w ostatnich latach części zamiennych (materiałów przestarzałych);

- analiza wartościowa ABC części zamiennych

- określenie ilości dla części zamiennych o niskiej, normalnej i masowej rotacji.

Biorac pod uwage fakt, że wartość nabycia większości podzespołów może być znaczaca lub też okres realizacji zamówienia (odtworzenia zapasu) może trwać nawet klika miesiẹcy, należałoby oszacować ryzyko wystapienia konkretnego uszkodzenia oraz ewentualne koszty przestoju. Należy również uznać, że największe utrudnienia $\mathrm{w}$ zarządzaniu wielkością zapasów magazynowych występują w przypadku części zamiennych specjalnych i wolno rotujących. Szczególnie trudne może być ustalenie ich zapasu początkowego przy sprzęcie nowo wprowadzanym do eksploatacji i przy braku danych o zapotrzebowaniu na zapas w poprzednich horyzontach czasowych. W takich przypadkach należy uwzględnić następujące dane początkowe:

- strategiczność sprzętu technicznego (urządzenia) w instytucji lub jednostce organizacyjnej;

- ilość urządzeń określonego typu w przedsiębiorstwie;

- ilość egzemplarzy danej części (podzespołu) zamontowanej na sprzęcie oraz ich przynależność do grupy eksploatowanej według stanu technicznego lub w systemie planowo zapobiegawczym;

- oszacowane ryzyko wystąpienia uszkodzenia;

- dostępność części zamiennej u producenta, czas oraz przewidywany koszt dostawy;

- możliwość zastosowania zamienników;

- możliwości naprawy (regeneracji) oraz jakość dostarczanych komponentów;

- prognozowane straty działalności bieżącej w przypadku niedostępności materiału;

- możliwości magazynowe jednostki organizacyjnej. 


\section{Podsumowanie}

Pomimo wyznaczenia powyższych kierunków działania, w wielu zakładach i przedsiębiorstwach poziom zapasu części zamiennych przewyższa zwykle niezbędne minimum. Wynika to głównie $\mathrm{z}$ intuicyjnego dążenia do realizacji zadań na czas oraz całkowitego wyeliminowania przestojów sprzętu technicznego. Badania przeprowadzone $\mathrm{w}$ tym kierunku wykazują jednak, że koszty zapasów części zamiennych stanowią niejednokrotnie ponad 50\% całkowitych kosztów utrzymania w przedsiębiorstwach przemysłowych. Sam koszt części stanowi przy tym od $40 \%$ do $70 \%$ łącznych kosztów napraw, a nakłady ponoszone na zakup i utrzymanie części do momentu ich zabudowy w urządzeniach w sposób znaczny zwiększają koszty wytwórcze i eksploatacyjne. Z drugiej jednak strony aż 50\% całkowitych przestojów maszyn i urządzeń w różnych gałęziach przemysłu powodowane jest brakiem dostępności części w magazynach ${ }^{3 P}$.

Współczesne systemy wsparcia eksploatacji, powiązane zasadniczo $\mathrm{z}$ ruchem lub spoczynkiem środków zaopatrzenia w coraz większym stopniu implementują modele matematyczne oraz elementy rachunku prawdopodobieństwa. Należy jednak zaopatrzyć je w prawidłowe, kompletne i dobrze zinterpretowane dane. Efektywne zarządzanie wielkością zapasów części zamiennych stanowi problem organizacyjny $\mathrm{w}$ wielu przedsiębiorstwach $\mathrm{i}$ nie zawsze wdrożenie nowoczesnych rozwiązań daje pożądane rezultaty ${ }^{32}$. Działania te zbieżne są z istotą systemu logistycznego, który oprócz "rdzenia materialnego" zawiera $\mathrm{w}$ swej strukturze także sprzężone strumienie informacyjne i finansowe. Celem zastosowań informatyki $\mathrm{w}$ systemach eksploatacji oraz procesach logistycznych jest optymalizacja ilościowo - wartościowa, czyli obniżenie kosztów zasadniczej działalności (produkcja, eksploatacja sprzętu ...), zwiększenie efektywności działalności wytwórczej (produkcyjnej, usługowej, szkoleniowej ...) oraz obniżenie wielkości zamrożonego kapitału (np. wielkości utrzymywanych zapasów). Optymalna metoda planowania wielkości zapasów części zamiennych i podzespołów do techniki lotniczej $\mathrm{z}$ uwzględnieniem zmiennych warunków wynikających z intensywności eksploatacji, powinna zatem zwiększyć dostępność części i agregatów lotniczych, co w dłuższej perspektywie zwiększy poziom sprawności technicznej sprzętu przy jednoczesnej minimalizacji ponoszonych nakładów.

\section{Literatura}

[1] Cieciura M.. Zacharski J.: Metody probabilistyczne w ujęciu praktycznym, Warszawa 2007

[2] Grondys K. Klasvfikacia zapasu cześci zamiennych, Logistyka 5/2013, Instytut Logistyki i Magazynowania, Poznań 2013.

[3] Instrukcja stużby inżynieryjno - lotniczej lotnictwa Sit Zbrojnych RP, Bydgoszcz 2016,

[4] Kisperska-Moroń D., Krzyżaniak St. (red): Logistyka, Poznań 2009.

[5] Krawczyk St.: Logistyka. Teoria i praktyka, t1, t2, Warszawa 2011.

31 Grondys, 2013: 75

${ }^{32}$ Majewski, 2008: 21, 140-145 
The application of probability elements in optimizing supply of spare parts... Zastosowanie elementów probabilistyki w optymalizacji wielkości zapasów...

[6] Krzyżaniak St.: Podstawy zarzadzania zapasami w przykładach, Poznań 2005.

[7] Macha E.: Niezawodność maszyn, Politechnika Opolska, skrypt nr 237, Opole 2001.

[8] Majewski J.: Informatyka dla logistyki, Poznań 2008

[9] Mączyński W. Zarządzanie częściami zamiennymi, Inżynieria i utrzymanie ruchu $1 / 2013$.

[10] Mesjasz-Lech A.: Wybrane problemy zastosowania metod statystycznych $w$ analizie popytu $w$ przedsiębiorstwie, Logistyka 5/2011.

[11] Sarjusz - Wolski Z.: Sterowanie zapasami w przedsiębiorstwie, Warszawa 2000.

[12] Zbroja T.: Zarzadzanie produkcja i ustugami, www.ioz.pwr.wroc.pl.

[13] Author's share (Norbert Grzesik 30\% Tomasz Iwan 70\%):

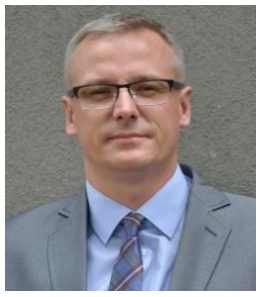

Plk dr hab. inz. Norbert Grzesik, Wydziat Lotnictwa Wyższej Szkoty Oficerskiej Sit Powietrznych w Dęblinie. Tytut magistra inżyniera uzyskat w 1999 roku na Wydziale Elektromechanicznym (obecnie Mechatroniki $i$ Lotnictwa) Wojskowej Akademii Technicznej w Warszawie. Doktorat ze specjalności budowa i eksploatacja maszyn uzyskat w 2006 roku na Politechnice Rzeszowskiej. Habilitacje w Instytucie Technicznym Wojsk Lotniczych w 2016 r. Specjalizacja to wykorzystanie rozmytych systemów eksperckich $w$ lotniczych systemach pokładowych $w$ zakresie wspomagania eksploatacji, bezpieczeństwa $i$ oceny niezawodności. Jest certyfikowanym specjalista w zakresie eksploatacji uzbrojenia $i$ awioniki wielu typów statków powietrznych (F-16, MiG-29, Su-22, Ts-11, Mi-2, W-3W i inne). Członek Europejskiego Stowarzyszenia Logiki Rozmytej i Centrum Naukowego Lotnictwa (wspótpraca naukowa WSOSP i ITWL) oraz Polskiego Naukowo-Technicznego Towarzystwa Eksploatacyjnego (Udziat 50\%).

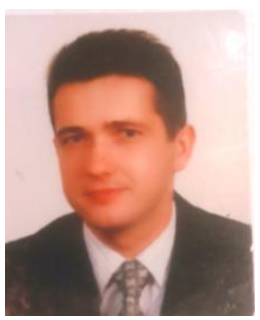

Mjr mgr inz. Tomasz Iwan, 41. Baza Lotnictwa Szkolnego w Dęblinie, zastępca przewodniczącego zespołu ds. wdrożenia do eksploatacji $w$ wojsku nowoczesnego sprzętu techniki lotniczej, doświadczony specjalista $w$ obszarze technicznego wsparcia eksploatacji, niezawodności technicznej a także certyfikowany doradca $w$ zakresie transportu drogowego towarów niebezpiecznych. Tytut magistra inżyniera uzyskat w 2000 roku na Wydziale Mechanicznym Wojskowej Akademii Technicznej w Warszawie. Początek pracy naukowej to szereg badań z zakresu inżynierii materiałowej, a w szczególności perspektywy zastosowań materiałów kompozytowych $w$ budowie i eksploatacji maszyn. Aktualny obszar zainteresowań to również optymalizacja procesów zarzadzania eksploatacja sprzętu techniki lotniczej oraz zwiększenie efektywności gospodarki materiałowo-technicznej w jednostkach i instytucjach wojskowych (Udziat 50\%). 